\title{
REPERTORIO BIBLIOGRÁFICO SOBRE EL DEFENSOR DEL PUEBLO ${ }^{1}$
}

\author{
JORGE ALGUACIL GONZÁLEZ-AURIOLES \\ Profesor Contratado Doctor de Derecho Constitucional \\ Universidad Nacional de Educación a Distancia \\ FERNANDO REVIRIEGO PICÓN \\ Profesor Titular de Derecho Constitucional \\ Universidad Nacional de Educación a Distancia
}

\section{NOTA PRELIMINAR}

La institución del Defensor del Pueblo no ha sido objeto hasta épocas recientes de una gran atención por parte de nuestros iuspublicistas, habiéndose generado una escasa bibliografía sobre el particular. Quizá quepa encontrar la explicación en el poco debate que generó en las Cortes Constituyentes y en el amplio consenso que desplegó su figura. En cualquier caso, lo cierto es que, por mor de la propia Constitución y de la Ley Orgánica que desarrolla esta institución, ha desplegado un papel no menor en la consolidación del régimen de libertades de nuestro orden constitucional.

En primer lugar, parece necesario plantearse los orígenes históricos y de Derecho comparado de esta institución. Todo proyecto constitucional encuentra en los antecedentes históricos y más en general en el estudio comparado una fuente básica de inspiración e impulso inicial; sin duda alguna, no es una excepción el caso que nos ocupa. En el primer apartado insertaremos pues aquellos estudios en lengua castellana que versen sobre los antecedentes históricos y de Derecho comparado del Defensor del Pueblo.

1 Agradecemos la valiosa ayuda prestada por el equipo de documentación del Defensor del Pueblo, y más concretamente, a las asesoras Pilar Lozano Pérez, María Jesús Mata Garrido, Visitación Molina Arranz y María José Pastor Afonso. Hay que destacar que Pilar Lozano Pérez es autora del primer Repertorio bibliográfico sobre el Defensor del Pueblo que fue publicado en la Revista de las Cortes Generales n. ${ }^{\circ} 29,1993$, págs. 273 a 311.

Este trabajo se ha elaborado en el marco del Proyecto de Investigación del Ministerio de Ciencia e Innovación DER 2009-10375 sobre “Constitución y Globalización. Transformaciones del Estado Constitucional y constitucionalización de espacios supranacionales". 
Pero además, la institución se encuadra en un régimen constitucional concreto, el que trae causa de nuestra norma suprema, y ello le dota de un sentido específico y de unas funciones particulares. El nexo de unión entre esta figura y nuestra vigente Constitución constituye el segundo apartado del presente repertorio.

Es cierto que la principal función del Defensor del Pueblo, tal y como establece el artículo 54 de nuestra norma suprema y el artículo 1 de su Ley Orgánica, es la defensa de los derechos comprendidos en el Título I de nuestra vigente Carta Magna; ello justifica, nos parece, que inmediatamente después del análisis general sobre la institución, insertemos un apartado sobre esta función general de garantía del régimen de derechos y libertades. Ahora bien, por imperativo de la propia Constitución, tal defensa se articula por medio del control de la Administración. Parece que la necesidad de afianzar la garantía del cumplimiento de estos derechos por una Administración que deviene, por mor de la Constitución, en un poder público al servicio de los ciudadanos (artículo $103 \mathrm{CE}$ ), mueve históricamente a la creación de esta institución. De hecho, la mayor parte de las actuaciones del Defensor del Pueblo se orientan a asegurar esta fiscalización de la Administración en orden a cumplir los principios que de ella se predican: eficacia, jerarquía, coordinación y sometimiento pleno a la ley y al derecho. En el muy importante y extenso apartado cuarto se insertan los trabajos dedicados a analizar esta tarea de fiscalización de la Administración.

El Defensor del Pueblo, por lo demás, no debemos olvidarlo, es un Alto Comisionado de las Cortes Generales y, en consecuencia, debe elevar a éstas un informe anual. A su vez, entre sus funciones de salvaguardia de la actividad de la Administración, se encuentran las propias recomendaciones que le puede efectuar. Estos informes y recomendaciones no han sido sólo instrumentos básicos sobre los se que ha cimentado el prestigio de esta institución, han constituido ocasionalmente impulsos de mejora legislativa o de actuación de la Administración. Al estudio de estos informes y recomendaciones y a sus efectos se han dedicado muy diversos autores, a los que recogemos en el que constituye el quinto apartado de este repertorio: otras medidas al alcance del Defensor del Pueblo (recomendaciones a la Administración, a los órganos legislativos e Informe Anual a las Cortes Generales).

La emergencia, por mor del proceso de descentralización política interna y del proceso de integración europea, de administraciones autonómicas y europea respectivamente, ha tenido como consecuencia la creación de defensores del pueblo específicos para cada una de estas nuevas administraciones. Los estudios que analizan los nuevos defensores del pueblo y sus relaciones con el Defensor del Pueblo español se encuadran en los apartados sexto y séptimo respectivamente. Por último, tanto el Defensor del Pueblo como los comisionados autonómicos han emitido, amén del informe anual, numerosos informes especiales sobre muy variadas materias. La relación de los mismos puede hacernos ver los diferentes temas que ocupan la actividad de esta importante institución y que a su vez la dotan de prestigio y reconocimiento. 
SUMARIO

I. Antecedentes históricos y Derecho comparado.

II. La institución y el Estado constitucional.

III. La función general de defensa de los derechos del Título Primero de la Constitución.

IV. En particular, la fiscalización de la Administración en orden a salvaguardar el respeto a estos derechos.

V. Otras medidas al alcance del Defensor del Pueblo (recomendaciones a la Administración, a los órganos legislativos e Informe Anual a las Cortes Generales).

VI. Comisionados parlamentarios autonómicos.

VII. Defensor del Pueblo europeo.

VIII. Documentos e informes.

\section{ANTECEDENTES HISTÓRICOS Y DERECHO COMPARADO}

ARCe Gordillo, J. P.: Análisis comparativo entre los criterios del Defensor del Pueblo (España) y del Procurador de los Derechos Humanos (Guatemala), en materia de derechos económicos, sociales y culturales, Universidad Nacional Autónoma de México, México, 1999.

armienta Calderón, G.: El Ombudsman y la protección de los Derechos Humanos, Porrúa, México, 1992.

ARrieta Cuevas, R.: "El Ombudsman en el Derecho comparado", Revista de Derecho Público, n. ${ }^{\circ} 20,1984$.

CAÑellas i Balcells, A.: "Las instituciones de ombudsman hoy: factores de democratización, transparencia y proximidad", El papel de los defensores del pueblo en un mundo en transición, Parlament de les Illes Balears, Palma de Mallorca, 2001, págs. 141 a 168.

Carballo ARMas, P.: El Defensor del Pueblo: el "Ombudsman" en España y en el derecho comparado, Tecnos, Madrid, 2003.

CARballo ARMas, P.: «Mito y realidad de la ombusdmanía: una reflexión a propósito de del Parliamentary Commissioner británico y el Mediateur francés", Revista de las Cortes Generales, n. 47, 1999, págs. 87 a 119.

CARPIZO, J.: "Algunas semejanzas entre el Ombudsman español y el mexicano", Cuestiones Constitucionales. Revista Mexicana de Derecho Constitucional, n. ${ }^{\circ}$ 9, 2003, págs. 67 a 100.

Chamizo de la Rubia, J.: "Los retos de la institución del Defensor del Pueblo ante el siglo XXI", El papel de los defensores del pueblo en un mundo en transición, Parlament de les Illes Balears, Palma de Mallorca, 2001, págs. 111 a 139. 
DAlla CoRTe, G.: "La vuelta al globo. Condiciones de la expansión de la figura del Ombudsman en el mundo a partir de la II Guerra Mundial", Revista Electrónica de Geografía y Ciencias Sociales, n. ${ }^{\circ}$ 69, 2000, págs. 1 a 12.

Díaz Revorio, F.J.: "Antecedentes y perspectivas para un Defensor del Pueblo en Castilla-La Mancha", Parlamento y Constitución, n. ${ }^{\circ}$ 1, 1997, págs. 189 a 200.

Escobar Roca, G.: Defensorías del Pueblo en Iberoamérica, Thomson-Aranzadi, Navarra, 2008.

Fatrén Guillén, V.: "Posibilidad y conveniencia de introducir a los Ombudsmännen en los ordenamientos jurídicos de naciones de habla ibérica", Revista de Estudios Políticos, n. ${ }^{14}$, 1980, págs. 21 a 63

FAIRÉN Guillén, V.: "Normas y notas sobre el Ombusdman de Suecia", Revista de Estudios Políticos n. ${ }^{\circ}$ 21, 1981, págs. 127 a 151

FAIRÉN GuilléN, V.: "Actividades recientes de algunos "Ombudsmännen" (incluido el Defensor del Pueblo)", Civitas. Revista Española de Derecho Administrativo, n. ${ }^{\circ}$ 46, 1985, págs. 227 a 256.

Fernández SAlmerón, M.: "Antecedentes de la figura del Defensor del Pueblo español,, @dministración. Ciberrevista de Derecho Administrativo, n. ${ }^{\circ} 19$, 2001.

Figueruelo Burrieza, A.: "Bases para un análisis comparado de la institución del Defensor del Pueblo en España y en Colombia", Estudios de Teoría del Estado y Derecho Constitucional en honor de Pablo Lucas Verdú, Vol. 3, R. Morodo Leoncio, P. De Vega (Coord.), Universidad Complutense, Madrid, 2001, págs. 1597 a 1630.

Fix Zamudio, H.: "Reflexiones comparativas sobre Ombudsman", Memoria de El Colegio Nacional, Vol. IX, 1970, págs. 99 a 149.

Gallego Huéscar, C., García Solís, J.: "El Defensor del Pueblo (Competencia, procedimiento y derecho comparado)", Revista de la Facultad de Derecho de la Universidad Complutense, n. ${ }^{\circ}$ 67, 1983, págs. 127 a 172.

García Valdeavellano, L.: "El Justicia de Aragón y las jurisdicciones especiales", VV.AA., Historia de las Instituciones españolas, Madrid, 1970, págs. 571 y SS.

García Vicente, F.: "Instrumentos supranacionales reguladores de figuras defensoriales: Unión Europea, Consejo de Europa, institutos especializados", Jornadas de coordinación entre Defensores del Pueblo, Defensor del Pueblo, Madrid, 2002, págs. 25 a 58.

Git-Robles y Gil-Delgado, A.: «El Defensor del Pueblo y su impacto en España y América Latina", Revista de la Asociación Iberoamericana del Ombudsman, n. ${ }^{\circ}$ 3, 1994, págs. 53 a 84.

GiL-Robles y GiL-Delgado, A.: "La institucionalización del Ombudsman y sus alternativas", Ombudsman, democracia y derechos humanos, Capitulo Boliviano del Ombudsman, La Paz, 1991, págs. 15 a 26.

Gil-Robles y Gil-Delgado, A.: "El Defensor del Pueblo", Memoria Congreso Mundial de Derechos Humanos, Vol. IV, Imprenta Nacional, Costa Rica, págs. 76 a 89. 
Giner De Grado, C.: Los ombudsmen europeos, Tibidabo Edicions, Barcelona, 1986.

Gros Espiell, H.: «El Ombusdman. Su interés en la actual situación de Hispanoamérica", Revista de las Cortes Generales, 1985, págs. 199 a 208

La Pergola, A.: "Ombudsman y Defensor del Pueblo: apuntes para una investigación comparada", Revista de Estudios Políticos, n. ${ }^{\circ}$ 7, 1979, págs. 69 a 92 .

Moris Marrodán, J.L.: "El Ombudsman llega a España”, Homenaje a José Antonio García-Trevijano, C. Albiñana García-Quintana (Ed.), Instituto de Estudios de Administración Local, Madrid, 1982, págs. 129 a 147.

Pellón Rivero, R.: El Defensor del Pueblo: legislación española y derecho comparado, Presidencia del Gobierno, Madrid, 1981.

Pellón Rivero, R.: «¿Un Ombudsman para España”, Documentación Administrativa, n. ${ }^{\circ} 170,1976$, págs. 99 a 134.

Pellón Rivero, R.: "La metamorfosis del Ombudsman", Documentación Administrativa, n. ${ }^{\circ} 161,1974$, págs. 17 a 80.

Peñarrubia IZA, J.M.: Ombudsman militar y Defensor del Pueblo: Estudio de Derecho Comparado y Español, Dilex, Madrid, 2001.

PITARCH, I.E.: "El Ombudsman en el Estado intervencionista", El control parlamentario del Gobierno en las democracias pluralistas, M. RAMírez JiMÉnEZ, (Ed.), Labor, Barcelona, 1978, págs. 420 a 433.

PUigPelat MARTí, F.: Estados compuestos y Ombudsman: experiencias europeas, Ombudsman, Universidad Autónoma de Barcelona, 2007.

Rodríguez Molina, J.: "El personero medieval, defensor de la comunidad", Aragón en la Edad Media Estudios de Economía y Sociedad (Homenaje a la profesora Carmen Orcástegui Gros, n. ${ }^{\circ}$ 2, 1999, págs. 1337 a 1354.

Rodríguez Molina, J.: "El personero, defensor de la comunidad ciudadana", Gaceta de Antropología, n. ${ }^{\circ}$ 17, 2000.

Rojas CASTRO, S.: "Análisis comparativo de dos ombudsmen regionales: el Defensor del Pueblo Europeo y la Comisión Interamericana de Derechos Humanos", Revista de Derecho de la Unión Europea, n. ${ }^{\circ}$ 4, 2003, págs. 105 a 134 .

Romero Burillo, A.M.: «El Defensor del Pueblo como puente. Entre la sociedad y el Estado", Bolivia: fin de un siglo y nuevas perspectivas políticas (19932003), P. Domingo (Coord.), Bellaterra, Barcelona, 2006, págs. 119 a 130.

Rowat, D.C., Giner De Grado, C.: El ombudsman en el mundo, Teide, Barcelona, 1990.

Sánchez Saudinós, J.M.: "La insoportable levedad del ser: el Defensor de los Derechos establecido en la Constitución francesa", en Cuadernos de Derecho Público, n. ${ }^{\circ}$ 34-35, 2008.

San PíO, C. DE: “El Ombudsman”, Boletín Informativo de Ciencia Política, n. ${ }^{\circ} 6$, 1971, págs. 167 a 176.

Soderman, J.: "El Ombudsman en Finlandia", Cuadernos de la Cátedra Fadrique Furió Cerol, n. ํ 2, 1993, págs. 97 a 104. 
Soderman, J.: "El Ombudsman en Finlandia", Azpilcueta. Cuadernos de Derecho, n. ${ }^{\circ}$ 7, 1992, págs. 37 a 50.

TAFARo, S.: "La herencia de los tribuni plebis", Revista General de Derecho Romano, n. ${ }^{\circ} 11,2008$.

Venegas Álvarez, S.: Origen y devenir del Ombudsman. ¿Una institución encomiable?, Universidad Nacional Autónoma de México, 1988.

Villalba Benítez, L.: La tutela de los derechos fundamentales y el Defensor del Pueblo: estudio comparativo de la institución del Defensor del Pueblo en España y Paraguay, Centro de Iniciativas de Cooperación al Desarrollo, Universidad de Alcalá, Alcalá de Henares, 2003.

Viñas Otero, A.: "Del Tribuno Plebis romano al Defensor del Pueblo (Ombudsman)", La Ley: Revista jurídica española de doctrina, jurisprudencia y bibliografía, n. ${ }^{\circ}$ 3, 1984, págs. 942 a 949.

VV.AA.: Congreso internacional "la experiencia del ombudsman en la actualidad", Comisión Nacional de Derechos Humanos, México, 1992.

VV.AA.: XXIV Jornadas de Coordinación entre Defensores del Pueblo, Andalucía, Defensor del Pueblo, 2009.

VV.AA.: XXIII Jornadas de Coordinación entre Defensores del Pueblo, Defensor del Pueblo, 2008.

VV.AA.: XXII Jornadas de Coordinación entre Defensores del Pueblo, Defensor del Pueblo, 2007.

VV.AA.: XXI Jornadas de Coordinación entre Defensores del Pueblo, Defensor del Pueblo, 2006.

VV.AA.: XX Jornadas de Coordinación entre Defensores del Pueblo, Defensor del Pueblo, 2005.

VV.AA.: XIX Jornadas de Coordinación entre Defensores del Pueblo, Defensor del Pueblo, 2004.

VV.AA.: XVIII Jornadas de Coordinación entre Defensores del Pueblo, Defensor del Pueblo, 2003.

VV.AA.: XVII Jornadas de Coordinación entre Defensores del Pueblo, Defensor del Pueblo, 2002.

VV.AA.: XVI Jornadas de Coordinación entre Defensores del Pueblo, Defensor del Pueblo, 2001.

VV.AA.: XV Jornadas de Coordinación entre Defensores del Pueblo, Defensor del Pueblo, 2000.

VV.AA.: XIV Jornadas de Coordinación entre Defensores del Pueblo, Defensor del Pueblo, 1999.

VV.AA.: XIII Jornadas de Coordinación entre Defensores del Pueblo, Defensor del Pueblo, 1998.

VV.AA.: XII Jornadas de Coordinación entre Defensores del Pueblo, Defensor del Pueblo, 1997.

VV.AA.: XI Jornadas de Coordinación entre Defensores del Pueblo, Defensor del Pueblo, 1996.

VV.AA.: X Jornadas de Coordinación entre Defensores del Pueblo, Defensor del Pueblo, 1995. 
VV.AA.: IX Jornadas de Coordinación entre Defensores del Pueblo, Defensor del Pueblo, 1994.

VV.AA.: VIII Jornadas de Coordinación entre Defensores del Pueblo, Defensor del Pueblo, 1993.

\section{LA INSTITUCIÓN Y EL ESTADO CONSTITUCIONAL}

Aguiar de Luque, L.: "Defensor del Pueblo", Temas básicos de Derecho constitucional, M. Aragón ReYes (Coord.), Vol. III, Civitas, Madrid, 2001, págs. 228 a 232.

Aguiar de Luque, L.: "Defensor del Pueblo", Enciclopedia Jurídica Básica, Vol. II, Civitas, Madrid, 1995, págs. 1954 a 1957.

Aguiar de Luque, L. Elvira Perales, A: "Intervención del Defensor del Pueblo en procedimientos jurisdiccionales", Diez años de la Ley Orgánica del Defensor del Pueblo. Problemas y perspectivas, Universidad Carlos III de Madrid, Madrid, 1992, págs. 159 a 186.

Aguilar Fernández-Hontoria, J.: “A propósito del Defensor del Pueblo. Los rasgos definidores de la posición jurídica de los órganos auxiliares", Revista de Administración Pública, n. ${ }^{\circ}$ 109, 1986, págs. 7 a 118.

Aguilar Fernández-Hontoria, J.: "A propósito del Defensor del Pueblo: los rasgos definidores de la posición jurídica de los órganos auxiliares", Las Cortes Generales, Vol. 1, Dirección General del Servicio Jurídico del Estado, Madrid, 1987, págs. 337 a 444.

Alisal SÁnchez, F.C.: "Constitución, Defensor del Pueblo e idioma", Tapia, n. ${ }^{\circ}$ 101, 1998, págs. 15 a 17.

Alzaga VillaAmil, O.: "Artículo 54", Comentario sistemático a la Constitución española de 1978, Ediciones del Foro, Madrid, 1978, págs. 349 a 356.

Aradillas, A.: Todo sobre el Defensor del Pueblo, Plaza \& Janés, Barcelona, 1985.

ARANO, M. L.: El Ombudsman y su recepción constitucional, Buenos Aires, Editorial de Belgrano, 1997.

Astarloa Huarte-Mendicoa, I.: "El Estatuto del Defensor del Pueblo", El Defensor del Pueblo en el Tratado de la Unión Europea, Universidad Carlos III, Madrid, 1993, págs. 155 a 200.

Astarloa Villena, F.: El Defensor del Pueblo en España, Universitat de les Illes Balears, Palma, 1994.

Astarloa Villena, F.: "Una introducción al estudio del Defensor del Pueblo", Cuadernos constitucionales de la Cátedra Fadrique Furió Ceriol, n. ${ }^{\circ}$ 2, 1993, págs. 75 a 96.

Aznar López, M.: "El Defensor del Pueblo”, Boletín de Estudios y Documentación de Servicios Sociales, n. ${ }^{\circ}$ 20, 1984, págs. 95 a 96.

Bar Cendón, A.: "El Defensor del Pueblo en el ordenamiento jurídico español", El desarrollo de la Constitución española de 1978, M. RAMírez JiMÉNeZ, (Ed.), Pórtico, Zaragoza, 1982, págs. 299 a 356. 
Bassols Coma, M.: "Inserción del Defensor del Pueblo en el sistema constitucional", El fortalecimiento del Ombudsman iberoamericano, Universidad de Alcalá de Henares, 1999, págs. 195 a 218.

Bardón Cuevas, M.: "El Defensor del Pueblo: artículo 54 de la Constitución española", La Constitución y la práctica del Derecho, Vol. 2, J. MARTínez-SImancas SÁnchez, M. Aragón Reyes (Coords.), Sopec, Madrid, 1998, págs. 1927 a 1940.

Blanco Canales, R.: "Artículo 54. Defensor del Pueblo", Portal de la Constitución, 2006.

Camacho, M.: "Joaquín Ruiz-Giménez Cortés, Defensor del Pueblo", La fuerza del diálogo: homenaje a Joaquín Ruiz-Giménez, Alianza Editorial, Madrid, 1997, págs. 43 a 51.

CaÑellas I Balcells, A.: "El Ombudsman y la función pública", X Jornadas de coordinación entre Defensores del Pueblo, Sindic de Greuges, Barcelona, 1995, págs. 241 a 247.

Carballo Martínez, G.: «El Defensor del Pueblo y los límites de la competencia universal", Boletín de Información. Ministerio de Justicia e Interior, n. ${ }^{\circ}$ 1756, 1995, págs. 4992 a 5042.

Carballo Martínez, G.: La mediación administrativa y el Defensor del Pueblo, Thomson-Aranzadi, Navarra, 2008.

Carrillo López, M.: "El Defensor del Pueblo: ¿factor de democratización?”, Revista Jurídica de Catalunya, Vol. 81, n. ${ }^{\circ}$ 4, 1982, págs.161 a 183.

Carrillo López, M.: "El Defensor del Pueblo entre el Estado y la sociedad civil”, Parlamento y sociedad civil, M.A. Aparicio (Coord.), Universidad de Barcelona, Barcelona, 1980, págs. 261 a 273

Carrillo López, M.: «El Defensor del Pueblo: ¿factor de democratización?", Revista Jurídica de Catalunya, n. ${ }^{\circ}$ 4, 1982, págs. 161 a 183.

Cascajo Castro, J.L.: "Los Defensores del Pueblo en el Estado social y democrático de Derecho: una perspectiva teórica", VV.AA. Anuario de jornadas: 1989-1990, Instituto Vasco de Administración Pública, Vitoria, 1991, págs. 107 a 125.

Cascajo Castro, J.L.: "Los Defensores del Pueblo en el Estado social y democrático de Derecho: una perspectiva teórica", Revista Vasca de Administración Pública, n. ${ }^{\circ} 24,1989$, págs. 43 a 54.

Cazorla Pérez, J., Cano Bueso, J.: "Los defensores del pueblo: imagen pública e interrelaciones jurídicas", Revista de Estudios Políticos, n. ${ }^{\circ}$ 59, 1988, págs. 27 a 47.

Cora Rodríguez, J.: "Los Comisionados Parlamentarios, la cultura democrática y la paz", XV Jornadas de Coordinación de Defensores del Pueblo, Ararteko, Vitoria, 2000, págs. 47 a 70.

Cruz Mera, A.: "El Defensor del Pueblo: 1. ${ }^{a}$ parte" Boletín de Información del Ministerio de Justicia, n. ${ }^{\circ} 1507,1988$, págs. 4444 a 4517.

Cruz Mera, A.: "El Defensor del Pueblo: $2^{\mathrm{a}}$ parte", Boletín de Información del Ministerio de Justicia, n. ${ }^{\circ}$ 1508, págs. 4733 a 4781.

Chamizo de la Rubia, J., Cañellas, A., Söderman, J.M.: El papel de los defensores 
del pueblo en un mundo en transición, Parlament de les Illes Balears, Palma de Mallorca, 2001.

Chamizo de la Rubia, J.: "Los retos de la institución del Defensor del Pueblo ante el siglo XXI", El papel de los defensores del pueblo en un mundo en transición, Parlament de les Illes Balears, Palma de Mallorca, 2001, págs. 111 a 139.

Dapena Baqueiro, M.: La Ley Orgánica del Defensor del Pueblo, Instituto Nacional de Prospectiva, Madrid, 1980.

ENÉRIz OlaecheA, F.J.: "La organización de la Constitución”, La Institución del Defensor del Pueblo de Navarra, Institución del Defensor del Pueblo de la Comunidad Foral de Navarra, 2008, págs. 185 a 209.

Fairén Guillén, V.: El Defensor del Pueblo (Ombusdman), Centro de Estudios Constitucionales, Madrid, 1982-1986.

FERnánDeZ, G.: "Defensor del Pueblo: una institución diferente y útil??, Revista del Colegio de Abogados de Córdoba, Córdoba, Argentina, n. ${ }^{\circ}$ 25, 1988.

Fernández Rodríguez, J.J.: "Los nuevos retos para las defensorías del Pueblo: bases para una reflexión", VV. AA., Memoria del X Congreso Iberoamericano de Derecho Constitucional, Tomo I, Instituto Iberoamericano de Derecho Constitucional, Lima, 2009.

Fernández Rodríguez, J.J.: "Prácticas en las defensorías del pueblo: redefiniendo las prácticas externas en la docencia del Derecho Constitucional?», Cotino Hueso, L. y Presno Linera, M.A. (Coords.), Innovación educativa en Derecho Constitucional. Reflexiones, métodos y experiencias de los docentes, PUV, Valencia, 2010.

Fernández Segado, F.: "El estatuto jurídico constitucional del Defensor del Pueblo en España", Ius et Praxis, Vol. 7, n. ${ }^{\circ}$ 1, 2001, págs. 47 a 108.

FERNÁNDEZ Segado, F.: «El estatuto jurídico-constitucional del Defensor del Pueblo en España", Anuario de Derechos Humanos, n. ㅇ 2, 2001, págs. 223 a 310.

Fix Zamudio, H.: "Ley Orgánica del Defensor del Pueblo", Gaceta Informativa de Legislación y Jurisprudencia, México, UNAM, 1981.

Gallego Huéscar, C., García Solé, F.: "El Defensor del Pueblo (Competencia, procedimiento y Derecho comparado)", Revista de la Facultad de Derecho de la Universidad Complutense, n. ${ }^{\circ}$ 67, 1982, págs. 127 a 172.

Gámiz Valencia, C.: "El Defensor del Pueblo (Ombudsman) en España”, Revista Internacional de Ciencias Administrativas, n. ${ }^{\circ} 4$, 1981, págs. 349 a 355.

Gil-Robles y Gil-Delgado, A.: "Artículo 54", Comentarios a la Constitución española, M.E. Casas BaAmonde, M. Rodríguez-Piñero, Fundación Wolters Kluwer, Madrid, 2008, págs. 1193 a 1198.

GiL-Robles y GIL-Delgado, A.: "Artículo 54", Comentarios a la Constitución española, M.E. Casas BaAmonde, M. Rodríguez-PiÑero y Bravo-Ferrer (Dirs.), Fundación Wolters Kluwer, Las Rozas, 2008.

Gil-Robles y Gil-Delgado, A.: «El Defensor del Pueblo, una vieja-nueva institución", La Constitución Española de 1978 en su XXV aniversario, M. Balado Ruiz-Gallegos, J.A. García Regueiro (Coords.), Bosch, Barcelona, 2003, págs. 427 a 434. 
GiL-Robles y GiL-Delgado, A.: “Joaquín Ruiz-Giménez y el Defensor del Pueblo", La fuerza del diálogo: homenaje a Joaquín Ruiz-Giménez, 1997, págs. 269 a 273.

Git-Robles y Gil-Delgado, A.: "Filosofía del Defensor del Pueblo", El Procurador del común: Defensor del Pueblo y Comunidades Autónomas, Cortes de Castilla y León-Universidad de Valladolid, Valladolid, 1995, págs. 21 a 36.

Gil-Robles y Gil-Delgado, A.: «El Defensor del Pueblo y su impacto en España y América Latina", Revista de la Asociación Iberoaméricana de Ombudsman, n. ${ }^{\circ}$ 3, 1994, págs. 53 a 84.

Gil Robles y Gil Delgado, A.: «La aportación de la institución del Defensor del Pueblo al mejor funcionamiento de la Administración de Justicia", Ombusdman judicial, perspectivas internacionales, Comisión Nacional de Derechos Humanos, México, 1993, págs. 81 a 153.

GiL-Robles y Gil-Delgado, A.: “Consideraciones en torno a la experiencia española del Defensor del Pueblo", Congreso Internacional. La experiencia del Ombudsman en la actualidad, Comisión Nacional de Derechos Humanos, México, 1992, págs. 33 a 38.

GiL-Robles y GiL-Delgado, A.: "La defensa de los ciudadanos por vía Defensor del Pueblo", Las relaciones entre Administración Local y Administración de Justicia, Vol. II, Barcelona, 1990, págs. 113 a 122.

GiL-Robles y GiL-Delgado, A.: Relaciones entre Derecho privado y Defensor del Pueblo, Universidad Popular Enrique Tierno Galván, Alicante, 1989.

Gil-Robles y Gil-Delgado, A.: «Relaciones entre Derecho Privado y Defensor del Pueblo", Centenario del Código Civil, F. Rico Pérez (Coord.), Vol. 1, 1986, págs. 285 a 292.

Gil Robles y Gil Delgado, A.: "Defensor del Pueblo y Administración de Justicia", Revista del Consejo General de los Ilustres Colegios de Procuradores de los Tribunales de España, n. ${ }^{\circ} 1$ y 2, 1981.

Gil-Robles y Gil-Delgado, A.: El Defensor del Pueblo: (comentarios en torno a una proposición de Ley Orgánica), Civitas, Madrid, 1979.

GiméNez NAVARRO, F.: "La mujer como reclamante ante los comisionados parlamentarios", XI Jornadas de Coordinación entre Defensores del Pueblo, Procurador del Común, León, 1997, págs. 227 a 283.

Gimeno Sendra, V.: "Artículo 162", Comentarios a la Constitución española, VV.AA., Fundación Wolters Kluwer, Madrid, 2008, págs. 692 a 2701.

Giner de Grado, C.: "Ruiz-Giménez Defensor del Pueblo", La fuerza del diálogo: homenaje a Joaquín Ruiz-Giménez, 1997, págs. 275 a 285.

Giner De Grado, C.: “¿Resulta eficaz la acción del Defensor del Pueblo?”, Razón y Fé, n. ${ }^{\circ} 1100,1990$, págs. 637 a 645.

Giner de Grado, C.: "Apéndice: El Ombusdman en España", El Ombusdman en el mundo, Teide, Barcelona, 1990, págs. 163 a 180.

Giner De Grado, C.: "Para qué sirve el Defensor del Pueblo", Revista de Fomento Social, n. ${ }^{\circ} 164,1986$, págs. 379 a 389.

Giner de Grado, C.: “El Defensor del Pueblo: tres años de experiencia”, Revista de Fomento Social, n. ${ }^{\circ}$ 162, 1986, págs. 119 a 133. 
Giner De Grado, C.: El Defensor del Pueblo en la teoría y en la práctica, Editorial Popular, Madrid, 1986.

Girón CARO, C: El régimen jurídico del Defensor del Pueblo, Universidad de Sevilla, Sevilla, 1997

González Ayala, M.D.: "Defensor del pueblo", Derechos y libertades: Revista del Instituto Bartolomé de las Casas, n. ${ }^{\circ} 1,1993$, págs. 461 a 472.

GonZÁlez Ayala, M.D.: "Informe sobre las actividades del Defensor del Pueblo en 1992", Derechos y libertades: Revista del Instituto Bartolomé de las Casas, n. ${ }^{\circ}$ 3, 1994, págs. 537 a 550.

Guerra-Librero Arroyo, G.: "El Ombudsman o defensor del ciudadano", Revista de Estudios de la Vida Local, n. ${ }^{\circ} 196,1977$, págs. 817 a 870.

Guerra Librero Arroyo, G.: "El Ombusdman, protector del ciudadano y defensor de la equidad", Impuestos de la Hacienda Pública n. ${ }^{\circ}$ 365, 1973.

IbáÑ̃zz García, I.: Derecho de petición y derecho de queja, Dykinson, Madrid, 1993, págs. 41 a 52.

López de Silanes, J.: "La institución del Defensor del Pueblo", Boletín Económico de Información Comercial Española, n. ${ }^{\circ}$ 2001/2002, 1985 págs. 2297 a 300 y págs. 3079 a 3083.

Maiorano, J.L.: "Apuntes para un debate parlamentario: el Defensor del Pueblo español", La Ley. Revista Jurídica Argentina de Doctrina Jurisprudencial y Bibliografía, n. ${ }^{\circ}$ 189, 1984, págs. 1 a 4 y 13.

Márquez Reviriego, V.: "El Defensor del Pueblo", Apuntes parlamentarios, Congreso de los Diputados, Madrid, 1996, págs. 428 a 432.

Martín-Retortillo Baquer, L.: "Garantías de los derechos. Control judicial, amparo.Ombudsman", El Derecho público a finales de siglo: una perspectiva Iberoamericana, M. Clavero arévalo (Coord.), Fundación BBV- Civitas, Madrid, 1997, págs. 635-648

Martínez Hernández, E.: "Defensor del Pueblo", Prontuario de Derecho constitucional, P. Lucas Verdú (Comp.), Comares, Granada, 1996, págs. 85 a 87.

Mora, A.: El libro del Defensor del Pueblo, Defensor del Pueblo, Madrid, 2003.

Moris MARrodÁn, J.L.: "El Ombudsman llega a España", Homenaje a José Antonio García-Trevijano, Instituto de Estudios de Administración Local, Madrid, 1982, págs. 129 a 147.

Múgica Herzog, E.: «El Defensor del Pueblo: un puente entre el ciudadano y la Administración", Enfoques de España, Vol. 1, 2006, págs. 235 a 248.

Múgica Herzog, E.: "El Defensor del Pueblo institución constitucional”, Diwan Al Madhalim: revue spécialisée semestrielle, n. 3, 2005, págs. 9 a 12.

Oehuing Ruíz, H.: "El Defensor del Pueblo: algunos problemas en su adaptación orgánico funcional", Revista de Estudios Políticos, n. ${ }^{\circ}$ 72, 1991, págs. 89 a 128 .

Ortiz González, A.L.: "El Defensor del Pueblo y los menores", El menor en la legislación actual, 1998, págs. 179 a 188.

Peces-Barba Martínez, G.: "Una recapitulación y unas propuestas", Diez años de la Ley Orgánica del Defensor del Pueblo, Universidad Carlos III, Madrid, 1992, págs. 279 a 304. 
Pellón Rivero, R.: El Defensor del Pueblo. Legislación española, derecho comparado, Presidencia del Gobierno, Madrid, 1981.

Pellón Rivero, R.: “¿Un Ombusdman para España?", Documentación Administrativa, n. ${ }^{\circ} 170,1976$, págs. 99 a 134.

Pérez Calvo, A.: "Artículo 54. El Defensor del Pueblo", Comentarios a la Constitución española de 1978, O. Alzaga Villaamil (Dir.), Cortes Generales, Madrid, 1996, Vol. IV, págs. 533 a 579.

Pérez Calvo, A.: "Defensor del Pueblo", Diccionario del Sistema Político Español, J.J. GonZález Encinar (Dir.), Akal, Madrid, 1984, págs. 191 a 198.

Pérez Calvo, A.: "Comentario al artículo 54: El Defensor del Pueblo", Comentarios a las Leyes Políticas. Constitución Española de 1978, O. Alzaga VillaAmil (Dir.), Editoriales de Derecho Reunidas, Madrid, 1984, págs. 497 a 552.

Pérez Calvo, A.: "Defensor del Pueblo y Comisionado parlamentario vasco", Revista Vasca de Administración Pública, n. 3, 1982, págs. 31 a 35.

Pérez Calvo, A.: "Rasgos esenciales del Defensor del Pueblo según la Constitución y la Ley Orgánica 3/1981, de 6 de abril", Revista de Derecho Politico, n. ${ }^{\circ} 11,1981$, págs. 67 a 81.

Pérez Calvo, A.: "Aspectos constitucionales del Defensor del Pueblo", Revista de Derecho Político, n. ${ }^{\circ} 4,1979$, págs. 79 a 105.

Pérez Francesch, J.L.: "El Defensor del Pueblo en España: balance de veinticinco años de experiencia constitucional", Revista de Estudios Políticos, n. ${ }^{\circ}$ 128, 2005, págs. 59 a 86.

Pérez Francesch, J.L.: "El Defensor del Pueblo”, Constitución: desarrollo, rasgos de identidad y valoración en el XXV aniversario (1978-2003), J.C. GAVARA DE CARA (Coord.), 2004, págs. 191 a 211.

Pérez-Ugena Coromina, M.: Defensor del Pueblo y Cortes Generales, Congreso de los Diputados, Madrid, 1996.

Pérez-Ugena Coromina, M.: "Defensor del Pueblo y partidos políticos", Revista de la Facultad de Derecho de la Universidad Complutense, n. ${ }^{\circ} 82,1992$ a 1993, págs. 339 a 348.

PitarCH, I.E.: "El Ombudsman en el Estado intervencionista", El control parlamentario del Gobierno en las democracias pluralistas, M. RAMíREZ JIMÉNEZ, (Ed.), Labor, Barcelona, 1978, págs. 420 a 433.

Retuerto Buades, M.: «El Defensor del Pueblo, institución de garantía no jurisdiccional del Derecho nacional y comunitario", Revista de las Cortes Generales, n. ${ }^{\circ} 29,1993$, págs. 7 a 20.

Rovira Viñas, A.: "Veinte años del Defensor del Pueblo", Revista de Derecho Político, n. ${ }^{\circ}$ 58-59, 2003-2004, págs. 355 a 370.

Rovira Viñas, A.: (Dir.), Comentarios a la Ley Orgánica del Defensor del Pueblo, Defensor del Pueblo- Aranzadi, 2002.

Rovira Viñas, A.: "El Defensor del Pueblo en España", La Defensoría del Pueblo: retos y posibilidades, CAJ, Lima, 1995, págs. 73 a 88.

RODRíguez Molina, J.: "El personero, defensor de la comunidad ciudadana", Gazeta de antropología, n. ${ }^{\circ}$ 17, 2001. 
Ruiz-Giménez Cortés, J.: «El Defensor del Pueblo como institución constitucional, como problema y como utopía", Las Cortes Generales, Vol. I, Instituto de Estudios Fiscales, Madrid, 1987, págs. 311 a 334.

Ruiz-Giménez Cortés, J.: «El Defensor del Pueblo y las instituciones democráticas", España hoy, Unión Editorial, Madrid, 1984, págs. 79 a 92.

Ruiz-Giménez de Aguilar, A., Ubeda de los Cobos, M.L.: "Constitución española, Defensor del Pueblo y Colegios Profesionales", La Constitución Española de 1978 en su XXV aniversario, M.BALAdO RuIZ-Gallegos, J.A. GARCíA Regueiro (Coords.), Bosch, Barcelona, 2003, págs. 1329 a 1334.

SÁnchez Saudinós, J.M.: "El Defensor del Pueblo", La administración pública española, J. Rodríguez-Arana MuÑoz (Dir.), Instituto Nacional de Administración Pública, Madrid, 2002, págs. 697 a 720.

SANPEDRo, V.: “¿Defensor del pueblo?», El Viejo topo, n. ${ }^{\circ}$ 152, 2001, pág. 11.

SANZ Moreno, F.: "Defensor del Pueblo y Parlamento (relaciones con las Cámaras)", Diez años de la Ley Orgánica del Defensor del Pueblo. Problemas y perspectivas, Universidad Carlos III, Madrid, 1982, págs. 5 a 70.

Sevilla Merino, J.: "Los derechos de las mujeres en los defensores del pueblo", Mujer y Constitución en España, VV.AA., Centro de Estudios Políticos y Constitucionales, Madrid, 2000, págs. 537 a 559.

SFIKAS, D.: "El Ombudsman en España", Reforma Administrativa, n. ${ }^{\circ} 43 / 44$, 1990, págs. 109 a 115.

Soriano Díaz, R.L.: "Los puntos negros de la institución del Defensor del Pueblo", Jueces para la democracia, n. ${ }^{\circ} 35,1999$, págs. 3 a 9.

Terrón Reynolds, F. (Ed.), Régimen jurídico del Defensor del Pueblo, $2^{\mathrm{a}}$ ed, Defensor del Pueblo, Madrid, 2002.

Ull Pont, E.: "El Defensor del Pueblo", Lecturas sobre la Constitución Española, UNED, Madrid, 1978, págs. 467 a 491.

Varela Suanzes-Carpegna, J.: "La naturaleza jurídica del Defensor del Pueblo", Revista Española de Derecho Constitucional, n. ${ }^{\circ} 8,1983$, págs. 63 a 80.

Vera Santos, J.M.: El Defensor del Pueblo en la Constitución y en los Estatutos de Autonomía, Centro de Estudios Políticos y Constitucionales, Madrid, 2002.

Viñas Otero, A.: "Del Tribuno Plebis romano al Defensor del Pueblo (Ombudsman)", La Ley: Revista juridica española de doctrina, jurisprudencia y bibliografía, n. ${ }^{\circ}$ 3, 1984, págs. 942 a 949.

Visiedo Mazón, F.J.: «El Ombudsman, el Defensor del Pueblo en la Constitución Española", Estudios sobre la Constitución Española de 1978, Universidad de Valencia, Valencia, 1980, págs. 217 a 229.

VV.AA.: Diez años de la Ley Orgánica del Defensor del Pueblo problemas y perspectivas, Universidad Carlos III, Madrid, 1992.

Zambrano Pasquel, A.: "Ministerio Público, asistencia legal y el Defensor del Pueblo", Eguzkilore: Cuaderno del Instituto Vasco de Criminología, n. ${ }^{\circ} 12$, 1998, págs. 319 a 338. 


\section{LA FUNCIÓN GENERAL DE DEFENSA DE LOS DERECHOS DEL TÍTULO PRIMERO DE LA CONSTITUCIÓN}

Abad Yupanqui, S.: "La legitimación del Defensor del Pueblo español en materia de amparo, ¿una experiencia a tomar en consideración?", Anuario Jurídico, Lima, n. ${ }^{\circ} 1,1991$.

Aguiar de Luque, L; Elvira Perales, A.: «Intervención del Defensor del Pueblo en procedimientos jurisdiccionales", Diez años de Ley Orgánica del Defensor del Pueblo. Problemas y perspectivas, Universidad Carlos III, Madrid, 1992, págs. 159 a 186.

Anguita Susi, A.: El Defensor del Pueblo andaluz y la tutela de los derechos fundamentales: medios, mecanismos y procedimiento, Tirant lo Blanch, Valencia, 2006.

ANDRÉs Alonso, F.: "Las garantías de los derechos fundamentales", XVI Jornadas de Coordinación Defensores del Pueblo, Palacio del Senado, Madrid, 2002, págs. 341 a 353.

Arce Gordillo, J.P.: Análisis comparativo entre los criterios del Defensor del Pueblo (España) y del Procurador de los Derechos Humanos (Guatemala) en materia de derechos económicos, sociales y culturales, UNAM/Corte de Constitucionalidad de Guatemala, México, 1999.

Aznar López, M.: «El Defensor del Pueblo y la protección del derecho a la Seguridad Social", Las Cortes Generales, Vol. 1, Dirección General del Servicio Jurídico del Estado, Madrid, 1987, págs. 639 a 664.

Aznar López, M.: "El Defensor del Pueblo y los derechos de la infancia", Revista del Ministerio de Trabajo e Inmigración, n. ${ }^{\circ}$ 5, 1997, págs. 99 a 108.

AzNAR López, M.: "La protección de los derechos de la infancia y el Defensor del Pueblo", El menor y la familia: conflictos e implicaciones, J. RoDríGuEz Torrente (Ed. lit.), Universidad Pontificia Comillas, Madrid, 1998, págs. 153 a 172

Aznar López, M.: "Los derechos de la infancia desde la perspectiva del Defensor del pueblo", Quórum: Revista de pensamiento iberoamericano, n. ${ }^{\circ} 2$, 2001, págs. 175 a 186.

Aznar López, M.: "El Defensor del Pueblo y la protección de los derechos de las personas con minusvalía", Versión Celeste n. ${ }^{\circ}$ 4, 1992, págs. 15 a 16.

Balado Ruiz-Gallegos, M., García Regueiro, J.A.: "El Defensor del Pueblo como garante de los Derechos Fundamentales: pasado, presente y futuro", La Constitución Española de 1978 en su XXV aniversario, L. Prieto Olmos, Bosch, Barcelona, 2003, págs. 1271 a 1278.

Baldira Munte, F.: "La legitimación del Defensor del Pueblo para interponer recursos de inconstitucionalidad", Boletín de los Colegios de Abogados de Aragón, n. ${ }^{\circ} 133,1993$, págs. 34 a 44.

BARTLLeT i CASTELlá, E.R.: "Ombusdman y jurisdicción contenciosa", Las relaciones entre Administración Local y Administración de Justicia, vol 2, Ayuntamiento de Barcelona y Consejo General del Poder Judicial, Barcelona, 1990, págs. 129 a 1137. 
Canales Allende, J.M, «El Defensor del Pueblo y los pensionistas de la Seguridad Social", Presupuesto y Gasto Público n. ${ }^{\circ}$ 7, 1980, págs. 17 a 22.

Colomer Viadel, A.: “El Defensor del pueblo: un órgano político-administrativo de protección de los derechos", Revista de Derecho Político, n. ${ }^{\circ}$ 71-72, 2008, págs. 57 a 83.

Corchete Martín, M.J.: El Defensor del Pueblo y la protección de los derechos, Universidad de Salamanca, 2001.

Corchete Martín, M.J.: «El Defensor del Pueblo y la protección de los derechos", Acta salmanticensia. Estudios jurídicos, Universidad de Salamanca, 2001, págs. 189 a 198.

Chamizo De la Rubia, J.: "Aportaciones del Defensor del Pueblo Andaluz para la incorporación de los derechos sociales al Estatuto de Autonomía para Andalucía", Nuevas Políticas Públicas, n. ${ }^{\circ}$ 2, Los derechos sociales, Instituto Andaluz de Administración Pública, Sevilla, 2006.

FERnÁNDEZ Aparicio, J.M.: “Defensor del pueblo: presentación sobre los recursos ante la discriminación racial y los ataques racistas", Recursos legales contra la discriminación racial y los ataques racistas, C.J. GORTÁzAR ROTAEChe, J.M. Ruiz DE Huidobro De Carlos (Coords.), Delegación Diocesana de Inmigrantes, Madrid, 1994, págs. 69 a 76.

Folchi i Bonafonte, I., Bayona I Rocamora, A., "La defensa de los derechos fundamentales y de las libertades públicas en el ámbito de las Comunidades Autónomas. Instituciones similares a la del Defensor del Pueblo", Revista Vasca de Administración Pública, n. ㅇ 6, 1983, págs. 73 a 119.

Foraster SERRA, M.: "Las Sentencias del Tribunal Constitucional sobre la normativa de la objeción de conciencia al servicio militar", Revista Jurídica de Catalunya, n. ${ }^{\circ}$ 2, 1988, págs. 181 a 194.

García Murcia, J.: «Sobre el desarrollo de la actividad sindical en los establecimientos militares y otros aspectos de la libertad sindical (comentario a la sentencia del Tribunal Constitucional 101/1991, de 13 de mayo)", Revista Española de Derecho del Trabajo, n. ${ }^{\circ}$ 53, 1992, págs. 433 a 452.

Gil-Robles y Gil-Delgado, A.: «El Defensor del Pueblo y el Tribunal Constitucional", Libro Homenaje al Profesor Eduardo Ortiz Ortiz, J.C. CASTRO Loría, Universidad Autónoma de Centroamérica, Costa Rica, 1994, págs. 241 a 265.

Gil-Robles y Gil-Delgado, A.: "La defensa de los ciudadanos por vía del Defensor del Pueblo", Las relaciones entre Administración Local y Administracion de Justicia, Vol. II, Barcelona, 1990, págs. 113 a 122.

Gil Robles y Gil-Delgado, A.: «El procurador ante las nuevas Instituciones Constitucionales para la defensa de los derechos de los ciudadanos", $L i$ bro del VI Congreso Nacional de los Procuradores de los Tribunales de España, 1980, págs. 103 a 118.

Giner De Grado, C.: «El Defensor del Pueblo garante de los derechos fundamentales", Laicado, n. ${ }^{\circ} 75,1986$, págs. 53 a 62.

González Moreno, B.: «El Defensor del Pueblo y la defensa constitucional del Derecho de Libertad ideológica, religiosa y de culto", La libertad religiosa 
$y$ de conciencia ante la justicia constitucional, J. MARTínez-Torrón, (Coord.), Comares, Granada, 1998, págs. 509 a 524.

Markiegi Candina, X.: "Problemática de las personas de origen extranjero percibida a partir de nuestras actuaciones", XII Jornadas de Coordinación entre Defensores del Pueblo, Defensor del Pueblo Andaluz, Sevilla, 1998, págs. 275 a 287.

Martín-Retortillo Baquer, L.: "El ruido en el informe del Defensor del Pueblo sobre 1994", Revista de estudios de la administración local y autonómica, n. ${ }^{\circ} 265,1995$, págs. 85 a 116.

Martín Retortillo baquer, L.: "El ruido en el Informe del Defensor del Pueblo de 1994", Revista de Administración Local y Autonómica n. ${ }^{\circ}$ 265, 1995, págs. 85 a 115 .

MarTínez Sospedra, M.: “Constitución española y objeción de conciencia (acerca de las sentencias del Tribunal Constitucional 160 y 161/1987, de 27 de octubre)", Revista General de Derecho, n. ${ }^{\circ}$ 523, 1988, págs. 1751 a 1774 .

Merino Senovilla, H.: "Derechos fundamentales y prisión desde la perspectiva de los defensores del pueblo", El Juez de Vigilancia Penitenciaria y el tratamiento penitenciario, Consejo General del Poder Judicial, Madrid, 2006, págs. 205 a 236.

Miquel CAlatayud, J.A.: "Consideraciones referentes a la sentencia del Tribunal Constitucional acerca de determinados preceptos de la Ley Orgánica sobre los Derechos y Libertades de los Extranjeros en España", La Ley, Vol. I, 1990, págs. 975 a 999.

Montesinos SánChez, M.N.: "Comentario a la resolución del Síndico de Agravios de la Comunidad Valenciana a la queja n. ${ }^{\circ}$ 960794: patrimonio histórico-libertad religiosa en la Administración", Estudios en homenaje al profesor Martínez Valls, n. ${ }^{\circ} 1,2000$, págs. 475 a 497.

Montesinos Sánchez, M.N.: "Las actuaciones del Defensor del Pueblo y de los comisionados autonómicos en materia de libertad religiosa y de conciencia y sus conexiones", La libertad religiosa y de conciencia ante la justicia constitucional, J. MarTínez-Torrón, (Coord.), Comares, Granada,1998, págs. 669 a 685.

Montesinos SÁnchez, M.N.: "Defensor del Pueblo y derechos fundamentales: la libertad religiosa en la Administración", Revista General de Derecho, n. ${ }^{\circ}$ 637/638, 1997, págs. 12142 a 12163.

Múgica Herzog, E.: "El Defensor del Pueblo y los derechos de las personas sin hogar", Temas para el debate, n. ${ }^{\circ} 174$ (mayo), 2009, págs. 23 a 26.

Múgica Herzog, E.: “El Defensor del Pueblo y su actuación en los ámbitos de la extranjería y la inmigración", Inmigración, Estado y Derecho: perspectivas desde el siglo XXI, Balado Ruiz-Gallegos, M., (Coord.), Bosch, Barcelona, 2008, págs. 83 a 100.

Ortiz GonzÁlez, A.L.: "La figura del Defensor del Pueblo y actuaciones con las personas privadas de libertad", Cuadernos de Derecho Judicial, n. ${ }^{\circ} 22$, 2006, págs. 259 a 339. 
OrTiZ GonZÁLEZ, A.L.: "Análisis legal y reglamentario de las medidas privativas de libertad. Especial consideración a las condiciones de internamiento en centro cerrado según las actuaciones realizadas desde el Defensor del Pueblo", Cuadernos de Derecho Judicial, n. ${ }^{\circ}$ 25, 2005, págs. 39 a 78.

Ortiz González, A.L.: "Aspectos jurídicos y prácticos más controvertidos, apreciados en el informe del Defensor del Pueblo, en relación con la ley orgánica 5/2000", Nuevos retos que plantean los menores al derecho: II Jornadas sobre Derecho de los Menores, E. Lázaro González, I.V. Mayoral Narros, (Coords.), Universidad Pontificia Comillas, Madrid, 2004, págs. 131 a 154.

Ortiz González, A.L.: "Actuaciones del Defensor del Pueblo en relación con los derechos fundamentales de los menores", Revista Europea de Derechos Fundamentales, n. ${ }^{\circ}$ 4, 2004, págs. 319 a 332.

Ortiz González, A.L.: «La protección de los derechos de los menores desde el Defensor del Pueblo", Jornadas sobre derecho de los menores: Facultad de Derecho, Lázaro González, E., Mayoral Narros, I.V., (Coords.), 2003, págs. 99 a 124 .

Paino Navarrete, D; García- Calvo Rodríguez, L.F.: «El ejercicio de derechos sindicales en los establecimientos militares (comentario a la Sentencia del Tribunal Constitucional 101/1991, de 13 de mayo)", Revista Española de Derecho del Trabajo n. ${ }^{\circ}$ 58, 1993, págs. 281 a 287.

Pérez Calvo, A.: "La defensa de los derechos constitucionales de los ciudadanos por los comisionados parlamentarios. Actualidad y perspectivas", Jornadas sobre el Defensor del Pueblo Andaluz, G. RuIz Rico (Ed.), UNIA - Defensor del Pueblo Andaluz, Baeza, 2001, págs. 31 a 50.

Pérez-Ugena Coromina, M.: «El Defensor del Pueblo en los procesos de tutela constitucional", Revista de la Facultad de Derecho de la Universidad Complutense, n. ${ }^{\circ} 84$, 1993-1994, págs. 345 a 364.

PéreZ LuÑo, A. E.: "La contaminación de las libertades en la sociedad informatizada y las funciones del Defensor del Pueblo", Anuario de Derechos Humanos, n. ${ }^{\circ} 4$, 1986-1987, págs. 259 a 289.

PRieto Olmos, L.: "El Defensor del Pueblo como garante de los derechos fundamentales. Pasado, presente y futuro", La Constitución española de 1978 en su XXV aniversario, VV.AA., Bosch, Barcelona, 2003, págs. 1271 a 1277.

Retuerto BuAdes, M.: "La protección constitucional del menor a través del Defensor del Pueblo", La convención de los derechos del niño hacia el siglo XXI, V. Soler Sala, M.A. Verdugo Alonso (Coords.), Universidad de Salamanca, 1996, págs. 405 a 414.

Retuerto Buades, M.: «Procedimientos de legitimación de los Ombudsmen para interponer acciones populares y acciones de clase", International Ombudsman Journal, n. ${ }^{\circ}$ 13, 1995.

Retuerto BuAdes, M: "La experiencia del Defensor del Pueblo y la contaminación acústica", Gabinete de Estudios del Sindic de Greuges, 1995, págs. 85 a 95 . 
Retuerto Buades, M.: Protección a la salud desde la perspectiva del Defensor del Pueblo", El Médico, n. ${ }^{\circ}$ 582, 1995, págs. 12 a 17.

Retuerto Buades, M.: "La interdicción constitucional de discriminación por razón de sexo y la actuación del Defensor del Pueblo", Foro Internacional Mujer, Poder Político y Desarrollo, Instituto de la Mujer, Madrid, 1994, págs. 129 a 138.

Retuerto Buades, M.: "La protección constitucional del menor y el Defensor del Pueblo", VIII Jornadas de Coordinación entre Defensores del Pueblo, Defensor del Pueblo, 1993, págs. 131 a 144.

Retuerto Buades, M: «El sentido de la Institución en las garantías constitucionales de la vivienda", Boletín Informativo. Fundación cultural COAM n. 3 , 1992, págs. 4 a 9.

Retuerto Buades, M.: "La protección constitucional del menor y el Defensor del Pueblo", Menores, n. ${ }^{\circ}$ 17-18, 1989, págs. 27 a 41.

Retuerto Buades, M : «El Defensor del Pueblo y la Ley de defensa de los consumidores y usuarios", Dossier: ponencias y debates de las Jornadas de Consumo de la Comunidad Valenciana, Asociación Ciudadana de Consumidores de Valencia, Valencia, 1985, págs. 8 a 15.

Ruiz CÉzAR, M.: «El papel del Defensor del Pueblo en la protección y tutela de los derechos de los ciudadanos", Introducción a los derechos fundamentales: X jornadas de estudio, Vol. III, Dirección General del Servicio Jurídico del Estado, Madrid, 1988, págs. 2461 a 2492.

Ruiz-GimÉnez CoRTÉs, J.: «El papel del Defensor del Pueblo en la protección de los consumidores y usuarios", Estudios sobre consumo, n. ${ }^{\circ} 13$, 1988, págs. 63 a 75.

Sampaio Ventura, C.: "El papel del Defensor del Pueblo en la defensa de los derechos fundamentales", Quórum: Revista de pensamiento iberoamericano, n. ${ }^{\circ} 21,2008$, págs. 52 a 61.

SÁnchez LóPez, J.: "Defensa de los derechos (Defensor del Pueblo)", Reformas estatutarias y declaraciones de derechos, Balaguer Callejón, F., Ortega Alvarez, L., Cámara Villar, G., Montilla Martos, J.A., (Coords.), Instituto Andaluz de Administración Pública, Sevilla, 2008, págs. 63 a 78.

VILLA, J.M.: «El Defensor del Pueblo y la protección de los derechos de las personas en situación de exclusión social", Sesenta y más, n.. 252, 2006, págs. 31 a 33.

Villagómez Cebrián, A.J.: "Defensor del pueblo y tribunales de justicia: (aproximación a la renovación de las técnicas de control del Estado de Derecho), La Ley: Revista jurídica española de doctrina, jurisprudencia y bibliografía, n. ${ }^{\circ}$ 3, 1995, págs. 723 a 728. 


\section{EN PARTICULAR, LA FISCALIZACIÓN DE LA ADMINISTRACIÓN EN ORDEN A SALVAGUARDAR EL RESPETO A ESTOS DERECHOS}

Alonso UreBA, A.J.: «Las haciendas locales: problemas planteados ante el Defensor del Pueblo", Las Cortes Generales, Vol. 1, Dirección General del Servicio Jurídico del Estado, Madrid, 1987, págs. 533 a 562.

ARregui Minchero, B.: «El control de las corporaciones locales desde el ámbito parlamentario", Análisis local, n. ${ }^{\circ} 49,2003$, págs. 59 a 70.

Astarloa Villena, F.: «El Defensor del Pueblo y el control de la Administración Pública", Ciudadanos e instituciones en el constitucionalismo actual, J. Asensi Sabater, (Coord.), Tirant lo Blanch, Valencia, 1996, págs. 835 a 842.

Aznar López, M.: «El Defensor del Pueblo como gestor de caos sanitarios y sociales", Políticas sociales en Europa, n. ${ }^{\circ} 25-26,2009$, págs. 23 a 30.

Aznar López, M.: "Panorama de los servicios de urgencia del sistema público de salud: un enfoque desde la institución del Defensor del Pueblo", Mapfre Medicina, Vol. 4 (supl. 1), 1993, págs. 9 a 14.

AZnAR LóPEZ, M.: “La humanización de los servicios sociales de urgencia y los derechos de los pacientes. Su promoción y protección por el Defensor del Pueblo", Mapfre Medicina Vol. 4 (supl. 1), 1993, págs. 63 a 65.

Badía i Gascó, M.A; Fayos i Molet, A.M.: "Quejas de los ciudadanos en relación a actuaciones de los entes locales. Experiencias de cuatro años de funcionamiento", Las relaciones entre Administración Local y Administración de Justicia, Vol. II, Ayuntamiento de Barcelona. Concejalía de Presidencia, Barcelona, 1990, págs. 139 a 150.

BARTLETT i CASTELÀ, E.R.: "Ombudsman y jurisdicción contenciosa", Las relaciones entre Administración Local y Administracion de Justicia, Vol. II, Ayuntamiento de Barcelona, Barcelona, 1990, págs. 129 a 137.

Carro Fernández-Valmayor, J.L.: "Defensor del pueblo y Administración pública", Estudios sobre la Constitución española: Homenaje al profesor Eduardo García de Enterría, Vol. 3, L. MARTín-Retortillo BAquer (Coord.), Cívitas, Madrid, 1991, págs. 2669 a 2696.

Chacón Alonso, M.: «El Defensor del Pueblo y la Administración militar", Revista Española de Derecho Militar, n. ${ }^{\circ}$ 52, 1988, págs. 339 a 417.

Chacón Alonso, M.: "Informes del Defensor del Pueblo relacionados con la Administración militar", Revista Española de Derecho Militar, n. ${ }^{\circ}$ 58, 1991, págs. 237 a 318.

EMBiD Irujo, A.: «Los comisionados parlamentarios autonómicos y el control de la Administración local", Revista de Estudios de la Administración Local y Autonómica, n. ${ }^{\circ}$ 238, 1988, págs. 1101 a 1122.

FairÉn Guillén, V.: "El Defensor del Pueblo y las entidades locales", Las Cortes Generales, Vol. 2, Dirección General del Servicio Jurídico del Estado, Madrid, 1987, págs. 907 a 944.

Feltrer Rambaud, L., Retuerto Buades, M.: "La fiscalización y el control de los contratos administrativos: reflexiones desde el Defensor del Pueblo", Es- 
tudios sobre la contratación en las administraciones públicas, F.A. CASTILLO Blanco (Coord.), Comares, Granada, 1996, págs. 721 a 734.

Fernández Mateos, J.M.: "Informes del Defensor del Pueblo relacionados con la Administración militar", Revista Española de Derecho Militar, n. ${ }^{\circ}$ 59/60, 1992, págs. 191 a 249.

Gil-Robles y Gil-Delgado, A.: "El Defensor del Pueblo y el control parlamentario de la Administración", Anales de Derecho, n. 10, 1991, págs. 193 a 205.

Git-Robles y Gil-Delgado, A.: «La defensa de los ciudadanos por vía del Defensor del Pueblo", Las relaciones entre Administración Local y Administración de Justicia, Vol. II, Ayuntamiento de Barcelona, 1990, págs. 113 a 122.

GiL-Robles y Gil-Delgado, A.: El control parlamentario de la Administración (el Ombudsman), Instituto Nacional de Administración Pública, Madrid, 1981 ( $2^{a}$ edición).

GiL-Robles y Gil-Delgado, A.: El control parlamentario de la Administración, Instituto de Estudios Administrativos, Madrid, 1977.

GiL-Robles y Gil-Delgado, A.: «El Ombudsman como medio de control parlamentario de la Administración", Revista Universitaria, n. ${ }^{\circ}$ 81, Vol. XXI, 1972.

Giner De Grado, C.: "El Defensor del Pueblo: supervisor de la Administración", Información comercial española, n. ${ }^{\circ} 2034$, 1986, págs. 1569 a 1575.

Giner DE Grado, C.: "La España que se ve desde el Informe 85 del Defensor del Pueblo", Documentación social, n. ${ }^{\circ}$ 65, 1986, págs. 197 a 206.

Giner De Grado, C.: "El Defensor del Pueblo: Supervisor de la Administración", Boletín Económico de Información Comercial Española n. ${ }^{\circ}$ 2034, 1986, págs. 1569 a 1573

GoNZÁLEZ HABA,V.: «La Administración y función pública en el Informe anual del Defensor del Pueblo a las Cortes, 1983", Documentación Administrativa, n. ${ }^{\circ}$ 202, 1984, págs. 345 a 353.

GonzÁlez Pérez, J.: "Nuevos sistemas de control de la Administración Pública", Revista Española de Derecho Administrativo, n. ${ }^{\circ} 22$, 1979, págs. 399 a 430.

Granados Pérez, C.: "Defensor del Pueblo y Administración de Justicia (la supervisión de la Administración de Justicia)", Diez años de la Ley Orgánica del Defensor del Pueblo. Problemas y perspectivas, Universidad Carlos III, Madrid, 1992, págs. 219 a 249.

GómeZ Puente, M.: "Defensor del pueblo y administración tributaria", Escritos jurídicos en memoria de Luis Mateo Rodríguez, Vol. 1, Universidad de Cantabria, Santander, 1993, págs. 219 a 250.

Granados Pérez, C.: «Defensor del Pueblo y administración de justicia (la supervisión de la administración de justicia), Diez años de la Ley Orgánica del Defensor del Pueblo. Problemas y perspectivas, Universidad Carlos III, Madrid, 1992, págs. 23 a 67.

Lampreave Pérez, J.L.: "El Defensor del Pueblo y la Hacienda Pública", Derechos y garantías del contribuyente, Instituto de Estudios Fiscales, Madrid, 1983, págs. 373 a 407. 
LóPEZ DE Foronda VARGaS, F.: "Algunas reflexiones sobre las relaciones de los Defensores del Pueblo con las administraciones públicas", XIII Jornadas de Coordinación entre Defensores del Pueblo, Servicio de Publicaciones del Diputado del Común, Gran Canaria, 1999, págs. 123 a 177.

López Geta, J.M.: "La inspección de Hacienda ante el Defensor del Pueblo", Impuestos, n. ${ }^{\circ} 6,1983$, págs. 1 a 4.

MarTínez-CARDós Ruiz, J.L.: "Informe del Defensor del Pueblo, relacionado con la Administración Militar (1992)", $2^{\text {a }}$ parte", Revista Española de Derecho Militar, n. ${ }^{\circ}$ 66, 1995, págs. 395 a 410.

Martínez-Cardós Ruiz, J.L.: "Informe del Defensor del Pueblo relacionado con la Administración Militar (año 1993)", Revista Española de Derecho Militar, n. ${ }^{\circ}$ 67, 1996, págs. 433 a 441.

Montoro Puerto, M.: "La alternativa Defensor del Pueblo-Ministerio Fiscal", Revista Internacional de Ciencias Administrativas, n. ${ }^{\circ} 1,1980$, págs. 48 a 60.

Múgica Herzog, E.: «El Defensor del Pueblo: un puente entre el ciudadano y la Administración", Enfoques de España, Vol. 1, 2006, págs. 235 a 248.

Parejo Alfonso, L.: «El Defensor del Pueblo como institución de control de la Administración Pública (contenido y alcance de su función, procedimiento de actuación y tipos, efectos y publicidad de sus resoluciones)", Diez años de la Ley Orgánica del Defensor del Pueblo. Problemas y perspectivas, Universidad Carlos III, Madrid, 1992, págs. 103 a 132.

Peñalosa, G.: "Centros de menores: lo que está detrás del informe del Defensor del Pueblo", Iuris: Actualidad y práctica del derecho, n. ${ }^{\circ}$ 137, 2009, págs. 14 a 16 .

RAZquin LizarRaGa, M.M., "La colaboración de las administraciones públicas con el Defensor del Pueblo de Navarra", El Defensor del Pueblo de Navarra, A. Pérez Calvo (Coord.), Instituto Navarro de Administración Pública, 2009, págs. 207 a 234.

Retuerto Buades, M.: «El funcionamiento de la administración desde la aplicación de la Ley 30/1992, de 26 de noviembre, de régimen jurídico de las administraciones públicas y del procedimiento administrativo común: la experiencia del Defensor del Pueblo", Ciudadanos y reforma administrativa, Universidad Carlos III, Madrid, 1995, págs. 17 a 68.

Retuerto BuAdes, M.: «El ciudadano frente a la Administración: la Administración para el ciudadano", Laicado, n. ${ }^{\circ} 80,1989$, págs. 47 a 56.

Rich Oliva, M.: «Defensor del Pueblo. Procedimiento de tramitación de las quejas", Esquemas procesales, Vol. II, Bosch, Barcelona, 1991, págs. 493 a 497.

Rivero Ysern, J.L.: «Las funciones del Defensor del Pueblo en orden a la resolución extrajudicial de conflictos con la Administración Pública", Administración de Andalucia: Revista Andaluza de Administración Pública, n. ${ }^{\circ}$ 34, 1999, págs. 55 a 114.

SÁncheZ Morón, M.: "El Defensor del Pueblo como medio de control parlamentario de la administración", El fortalecimiento del Ombudsman iberoamericano, 1999, págs. 185 a 194. 
SÁnchez Saudinós, J.M.: "El Defensor del Pueblo", La Administración Pública española, J. Rodríguez-Arana MuÑoz (Dir.), Instituto Nacional de Administración Pública, Madrid, 2002, págs. 697 a 720.

SÁnchez Socías, I.: "Garantías del ciudadano frente a la Administración Pública. Panorama general", Gobierno y Administración en la Constitución, Vol. II, Instituto de Estudios Fiscales, Madrid, págs. 1727 a 1786.

SANTAOLALla LóPEZ, F.: "Las funciones parlamentarias en relación con los órganos auxiliares del Parlamento", A. Garrorena Morales (Ed.), El Parlamento y sus transformaciones actuales, Tecnos, Madrid, 1990, págs. 370 a 376.

Sanz Moreno, F.: “Defensor del Pueblo y Parlamento (relaciones con las Cámaras)", Diez años de la Ley Orgánica del Defensor del Pueblo. Problemas y perspectivas, Universidad Carlos III, Madrid, 1982, págs. 5 a 70.

SuÁrez Ruibal, E.J.: "Defensor del Pueblo y Administración Militar (19831989)", Cuadernos de estrategia, n. ${ }^{\circ}$ 50, 1992, págs. 91 a 116.

Villagómez Cebrián, A.J.: "Defensor del Pueblo y Tribunales de Justicia (aproximación a la renovación de las técnicas de control del Estado)", La Ley, n. ${ }^{\circ} 3828,1995$, págs. 1 a 3.

VV.AA, El Defensor del Pueblo y la Administración. Mesa redonda organizada por el Centro de Estudios Constitucionales y la Dirección General de Ordenación y Desarrollo Administrativo, junio de 1981, Presidencia de Gobierno, Madrid, 1983.

VV.AA, "El Defensor del Pueblo y el silencio administrativo", Documentación Administrativa n. $^{\circ}$ 208, 1986, págs. 209 a 217.

\section{OTRAS MEDIDAS AL ALCANCE DEL DEFENSOR DEL PUEBLO (RECOMENDACIONES A LA ADMINISTRACIÓN, A LOS ÓRGANOS LEGISLATIVOS E INFORME ANUAL A LAS CORTES GENERALES)}

Álvarez de Miranda y Torres, F.: "Sugerencias y recomendaciones que formula el Defensor del Pueblo", Teoría y Realidad Constitucional, n. ${ }^{\circ}$ 2, 1998, págs. 255 a 270.

ANGUITA Susi, A.: "Algunas notas en torno a la presentación parlamentaria del informe anual por los defensores del pueblo", Revista de Derecho Politico, n. 63, 2005, págs. 203 a 215.

AzNAR LóPeZ, M.: "El Defensor del Pueblo ante el abuso y la explotación sexual infantil", Atención al abuso sexual infantil, Instituto Madrileño del Menor y la Familia, Madrid, 2001, págs. 157 a 162.

Aznar López, M.: "Las personas mayores y el Defensor del Pueblo", Políticas sociales para las personas mayores en el próximo siglo, M.E. ENRIQUE Medina Tornero, M.J. Ruiz Luna (Coords.), Universidad de Murcia, 2000, págs. 315 a 330. 
Bassols Coma, M.: "El Defensor del Pueblo en el sistema constitucional: sus relaciones con las Cortes Generales; Administración Pública y Administración de Justicia", Anuario de la Facultad de Derecho de Alcalá de Henares, n. ${ }^{\circ}$ 8, 1998-1999, págs. 21 a 46.

Belda PÉrez-PEDRERo, E.: Instituciones de apoyo a gobiernos y parlamentos: (consejos, defensorías y cámaras de cuentas): sistema de designación y notas estatutarias, Tirant lo Blanch, Valencia, 2009.

Benito Anguita, F.: "Retos inmediatos de la sanidad desde la perspectiva del Defensor del Pueblo", Derecho y salud, Vol. 13, n. ${ }^{\circ}$ 1, 2005, págs. 35 a 44.

Carballo Martínez, G.: La mediación administrativa y el Defensor del Pueblo, Thomson-Aranzadi, Navarra, 2008.

CARro Fernández-VAlmayor, J.L.: "Defensor del pueblo y administración pública", Estudios sobre la Constitución española: Homenaje al profesor Eduardo García de Enterría, L. Martín-Retortillo Baquer (Coord.), Vol. 3, Cívitas, Madrid, 1991, págs. 2669 a 2696.

Cava de Llano Carrio, M.L.: "Los trabajos del Defensor del Pueblo secuestro internacional interparental de menores", I Congreso Jurídico Internacional sobre Traslado Ilícito de Menores: Zaragoza, 2004, págs. 25 a 39.

Chacón Alonso, M.: «Informes del Defensor del Pueblo relacionados con la Administración Militar", Revista Española de Derecho Militar, n. ${ }^{\circ}$ 58, 1991, págs. 237 a 318.

Chacón Alonso, M.: "Defensor del Pueblo y Administración Militar", Revista Española de Derecho Militar, n. ${ }^{\circ}$ 52, 1988, págs. 339 a 417.

Chamizo De la Rubia, J.: "Los retos de la institución del Defensor del Pueblo ante el siglo XXI", El papel de los defensores del pueblo en un mundo en transición, Parlament de les Illes Balears, Palma de Mallorca, 2001, págs. 111 a 139.

Chamizo de la Rubia, J.: "Medidas de los Defensores del Pueblo ante la falta de colaboración de las administraciones públicas: el empleo de la publicidad", XII Jornadas de coordinación entre Defensores del Pueblo, Diputado del Común, Gran Canaria, 1999, págs. 211 a 226.

Chamizo de la Rubia, J.: "Aportaciones del Defensor del Pueblo andaluz para la incorporación de los derechos sociales al Estatuto de Autonomía para Andalucía", Nuevas Políticas Públicas: Anuario multidisciplinar para la modernización de las Administraciones Públicas, n. ${ }^{2}$ 2, 2006, págs. 11 a 29.

DefENSOR Del Pueblo: Estudios y recomendaciones del Defensor del Pueblo sobre la atención residencial a personas con discapacidad y otros aspectos conexos, Defensor del Pueblo, Madrid, 1996.

Defensor Del Pueblo: Estudios y recomendaciones del Defensor del Pueblo sobre la la situación jurídica y asistencial del enfermo mental en España, Defensor del Pueblo, Madrid, 1991.

Delgado Pérez, I.: "Los informes especiales del Defensor del Pueblo Andaluz como expresión de su capacidad para emprender actuaciones de oficio", Justicia. Servicio Público, n 4, 2004, págs. 36 a 39. 
Díez Bueso, L.: "Los servicios sociales de atención a la tercera edad: el Defensor del Pueblo estatal y diversos defensores del pueblo autonómico", Los servicios sociales de atención a la tercera edad: el caso de Cataluña, 2002, págs. 363 a 378.

Díez Bueso, L.: «El modelo de Ombudsman autonómico y su reflejo en la tramitación de quejas", Revista Vasca de Administración Pública, n. ${ }^{\circ}$ 53, 1999, págs. 11 a 30.

Feltrer Rambaud, L., Retuerto Buades, M.: «La fiscalización y el control de los contratos administrativos: reflexiones desde el Defensor del Pueblon, Estudios sobre la contratación en las administraciones públicas, F.A. CASTILLO Blanco (Coord.), Comares, Granada, 1996, págs. 721 a 734.

Fernández Aparicio, J.M.: "El Defensor del Pueblo ante el problema de extranjería", Revista de servicios sociales y politica social, n. ${ }^{\circ} 28$, 1992, págs. 27 a 31.

Fernández Mateos, J.M.: "Apuntes sobre extranjería desde el Defensor del Pueblo", Ciudadanía y extranjería: derecho nacional y derecho comparado, McGraw-Hill, Madrid, 1998, págs. 111 a 126.

GARCía ÁlVAREZ, M.: "Los derechos de los ciudadanos frente a la privatización de los servicios públicos. Especial referencia a la intervención de los comisionados parlamentarios", XVII Jornadas de Coordinación de Defensores del Pueblo, Pamplona, 2003, págs. 223 a 258.

García Vicente, F.: "La protección penal de la función supervisora del Defensor del Pueblo y de los Comisionados parlamentarios autonómicos", XII Jornadas de coordinación entre Defensores del Pueblo, Defensor del Pueblo, Gran Canaria, 1999, págs. 237 a 243.

GiL-Robles y Gil-Delgado, A.: "La defensa de los ciudadanos por vía del Defensor del Pueblo", Las relaciones entre Administración Local y Administración de Justicia, Barcelona, 1990, Vol. II, págs. 113 a 122.

Jiménez Rodríguez, A.: "Arbitraje y Defensor del Pueblo", Estudios sobre el arbitraje: los temas claves, González MonTes, J.L. (coord.), La Ley, Madrid, 2008.

López CASANOVA, J.M.: “La defensa del patrimonio histórico-artístico: el papel de los comisionados parlamentarios", XIV Jornadas de Coordinación entre Defensores del Pueblo, El Justicia de Aragón, Zaragoza, 2000, págs. 67 a 120.

Maeztu Gregorio de Tejada, J.: "La pedagogía de la comunicación de los Ombudsmen con la opinión pública a través de los medios de comunicación social", X Jornadas de Coordinación entre Defensores del Pueblo, Sindic de Greuges, Barcelona, 1996, págs. 171 a 191.

MarTínez, B.J.: «El ciudadano y la defensa del patrimonio histórico: una perspectiva desde el Defensor del Pueblo de España", Anuario de la Universidad Internacional SEK, n. ${ }^{\circ}$ 6, 2000, págs. 103 a 118.

Monserrat Mesanza, J.B.: «Pedagogía de la comunicación de los Ombudsmen en la opinión pública a través de los medios de comunicación", X Jornadas de Coordinación entre Defensores del Pueblo, Síndic de Greuges, Barcelona, 1996, págs. 193 a 199. 
Ortiz GonZÁlez, A.L.: "La protección de los incapaces: Actuaciones del Defensor del Pueblo", Estudios de derecho judicial, n. ${ }^{\circ} 22$, 1999, págs. 231 a 276.

Ortiz GonZÁlez, A.L.: «Dilaciones indebidas en el proceso civil. Experiencia y propuestas desde el Defensor del Pueblo", El proceso en el siglo XXI y soluciones alternativas, 2006, págs. 261 a 277.

PADILLA, M.: "El Ombudsman y los medios de comunicación masivos", International Ombudsman Journal, n. ${ }^{\circ} 13,1995$, págs. 91 a 96.

Pérez-Ugena Coromina, M.: Defensor del Pueblo y Cortes Generales, Congreso de los Diputados, Madrid, 1996.

Pérez-Ugena Coromina, M.: "Defensor del Pueblo y partidos políticos", Revista de la Facultad de Derecho de la Universidad Complutense, n. ${ }^{\circ}$ 82, 1992 a 1993, págs. 339 a 348.

RAzQuin LizarRaga, J.A.: "Las relaciones con el Defensor del Pueblo de las Cortes Generales y con otras instituciones análogas", El Defensor del Pueblo de Navarra, A. Pérez CALvo (Coord.), Instituto Navarro de Administración Pública, 2009, págs. 303 a 342.

Rich Oliva, M.: "Defensor del Pueblo. Procedimiento de tramitación de las quejas", Esquemas procesales, Vol. II, Bosch, Barcelona, 1991, págs. 493 a 497.

RIVERO ISERN, J.L.: «La intervención de los defensores del pueblo en la solución convencional de conflictos", XII Jornadas de Coordinación entre Defensores del Pueblo, Defensor del Pueblo Andaluz, 1998, págs. 25 a 104.

Ruiz-Giménez Aguilar, A.: "Defensor del Pueblo y colegios profesionales", $L a$ Constitución española de 1978 en su XXV aniversario, VV.AA., Bosch, Barcelona, 2003, págs. 1329 a 1334.

SANTAOLALLA LÓPEZ, F.: "Las funciones parlamentarias en relación con los órganos auxiliares del Parlamento", A. Garrorena Morales (Ed.), El Parlamento y sus transformaciones actuales, Tecnos, Madrid, 1990, págs. 370 a 376.

Sainz Moreno, F.: “Defensor del Pueblo y Parlamento (relaciones con las Cámaras)", Diez años de la Ley Orgánica del Defensor del Pueblo. Problemas y perspectivas, Universidad Carlos III, Madrid, 1982, págs. 5 a 70.

URIBARRI, A.: "La relación de la institución del Defensor del Pueblo con las Cortes: el informe ordinario", El fortalecimiento del Ombudsman iberoamericano, 1999, págs. 85 a 109.

Zambrano SiLva, S.: «Sobre la necesidad de facilitar el acceso a la información derivada de la actuación de los comisionados parlamentarios: base de datos de las actuaciones contenidas en los informes anuales y especiales del Defensor del Pueblo andaluz", XVI Jornadas de Coordinación de Defensores del Pueblo, Madrid, 12 y 13 de noviembre de 2001, 2002, págs. 217 a 226.

VV.AA, "Reclamaciones sobre la actividad de las administraciones. Datos del Defensor del Pueblo y del Síndic des Greuges", Administración Local. Administración de Justicia. Barcelona, 1988, págs. 91 a 96. 


\section{COMISIONADOS PARLAMENTARIOS AUTONÓMICOS}

Alenza García, J.F.: "Las funciones y el ámbito competencial del Defensor del Pueblo de Navarra", El Defensor del Pueblo de Navarra, A. Pérez Calvo (Coord.), Instituto Navarro de Administración Pública, Pamplona, 2009, págs. 140 a 172.

Álvarez Asiáin, P.: "La oficina del Defensor del Pueblo de Navarra", El Defensor del Pueblo de Navarra, A. Pérez Calvo (Coord.), Instituto Navarro de Administración Pública, Pamplona, 2009, págs. 343 a 371.

Álvarez De Miranda y Torres, F.: "Presentación", X Jornadas de Coordinación entre Defensores del Pueblo, Síndic de Greuges, Barcelona, 1996, págs. 17 a 25.

Álvarez De Miranda y Torres, F.: «El marco competencial de colaboración y cooperación entre el Defensor del Pueblo y los Comisionados Autonómicos", XIII Jornadas de Coordinación entre Defensores del Pueblo, Servicio de Publicaciones del Diputado del Común, Gran Canaria, 1999, págs. 201 a 210.

ANGUita Susi, A.: El Defensor del Pueblo andaluz y la tutela de los derechos fundamentales: medios, mecanismos y procedimiento, Tirant lo Blanch, Valencia, 2006.

ANGUITA Susi, A.: "El futuro marco estatutario de los Comisionados parlamentarios autonómicos: especial referencia al Defensor del Pueblo Andaluz", La reforma de los Estatutos de Autonomía, G.J. Ruíz-Rico Ruiz, (Coord.), Tirant lo Blanch, Valencia, 2006, págs. 649 a 658.

ANguita Susi, A.: "La naturaleza unipersonal del Defensor del Pueblo Andaluz y la figura de los Adjuntos: algunas reflexiones sobre las reformas sufridas por la Ley del Defensor del Pueblo Andaluz", Administración de Andalucia: Revista Andaluza de Administración Pública, n. ${ }^{\circ} 48$, 2002, págs. 437 a 456.

ANGuita Susi, A.: «La descentralización del Estado social y la consolidación de los comisionados parlamentarios autonómicos", Parlamento y Constitución, n. ${ }^{\circ}$ 6, 2002, págs. 243 a 253.

Aragón Reyes, M.: "La Ley del Procurador del Común de Castilla y León", El Procurador del Común: Defensor del Pueblo y Comunidades Autónomas, Universidad de Valladolid-Cortes de Castilla y León, Valladolid, 1995, págs. 37 a 57.

ARIAS Diaz, I.: El Procurador General del Principado de Asturias: comentarios a su ley Reguladora, Gofer, Oviedo, 2006.

ArTeaga Izaguirre, J,M.: El Ararteko. Ombudsman del País Vasco en la teoría y en la práctica, Universidad de Deusto, Bilbao, 1994.

Arteaga Izaguirre, J,M.: "El Adjunto al Ararteko", Tercera Conferencia Europea del Ombudsman. La importancia del Ombudsman regional, Ararteko, Vitoria, 1993, págs. 168 a 172.

Ávila Rodríguez, C.M.: El Defensor del Pueblo y el Defensor del Pueblo Andaluz ante las políticas ambientales, Tirant lo Blanch, Valencia, 2007. 
Avila Rodríguez, C.M.: "Jornadas sobre el Defensor del Pueblo andaluz" Administración de Andalucía: Revista Andaluza de Administración Pública, n. ${ }^{\circ}$ 49, 2003, págs. 327 a 336.

Ávila Rodríguez, C.M.: «El Defensor del Pueblo Andaluz: Andalucía pionera en esta realidad autonómica", Administración de Andalucía. Revista Andaluza de Administración Pública, n. ${ }^{\circ}$ Extra 1, 2003, págs. 239 a 264.

Bandrés SÁnchez-Cruzart, J.M.: "El Justicia de Aragón", El Estatuto de Autonomía de Aragón de 1982, Diputación General de Aragón, Zaragoza, 1985, págs. 127 a 131.

BAR CENDÓn, A.: "El Justicia de Aragón en el Estatuto de Autonomía de 1982", Derecho público aragonés: estudios sobre el derecho de la Comunidad Autónoma de Aragón, A. EmBid Irujo (Dir.), Justicia de Aragón, Aragón, 1990, págs. 165 a 213.

BAR CENDÓN, A.: "La regulación jurídica de los defensores del pueblo regionales: ¿̇cooperación o conflicto?", Revista de Derecho Político, n. ${ }^{\circ}$ 18-19, 1983, págs. 77 a 109.

Bassols Coma, M.: "Las relaciones del Defensor del Pueblo con los comisionados parlamentarios de las Comunidades Autónomas", Anuario de la Facultad de Derecho de Alcalá de Henares, n. ${ }^{\circ}$ 7, 1997-1998, págs. 7 a 36.

BARTLETT i CASTELÀ, E.R.: "Aspectos innovadores a incorporar para afianzar la eficacia del Defensor del Pueblo Andaluz en el nuevo marco estatutario", El Defensor del Pueblo Andaluz y la Protección de Los Derechos Sociales en el Nuevo Estatuto de Autonomía para Andalucía, Instituto Andaluz de Administracion Publica, Sevilla, 2008, págs. 39 a 63.

Bartlett i Castelà, E.R.: El Síndic de Greuges, Institut d'Estudis AutonòmicsMarcial Pons, Madrid, 2001.

BARTLETT i CASTelà, E.R.: “La escolarización de niños inmigrantes en el informe del Defensor del Pueblo al Parlamento catalán", Perspectiva social, n. ${ }^{\circ} 42$, 1999, pags. 159 a 169.

BARTLETT I CASTElà, E.R.: "La mujer como reclamante ante los Ombudsman", $I$ Jornadas de Coordinación entre Defensores del Pueblo, Procurador del Común, León, 1997, págs. 285 a 296.

Bartlett i Castelà, E.R., Badía I Gasco, M.A.: "El Sindic de Greuges y los entes locales", Las relaciones entre Administración Local y la Administración de Justicia, 2 vols., Ajuntament, Barcelona, 1990, págs. 123 a 128.

Beltrán Aguirre, J.L.: "La investigación del Defensor del Pueblo de Navarra: las quejas de los particulares", La Institución del Defensor del Pueblo de Navarra, Institución del Defensor del Pueblo de la Comunidad Foral de Navarra, Pamplona, 2008, págs. 97 a 147.

Bermejo Vera, J.: «El Defensor del Pueblo y las figuras similares autonómicas: alcance de la coordinación y cooperación", Civitas. Revista Española de Derecho Administrativo, n. ${ }^{\circ}$ 68, 1990, págs. 509 a 532.

Biglino Campos, P.: El Procurador del Común: Defensor del Pueblo y Comunidades Autónomas, Cortes de Castilla y León - Universidad de Valladolid, Valladolid, 1995. 
Blanco Herranz, J.: "Los órganos dependientes del Parlamento Vasco. El caso del Tribunal Vasco de Cuentas Públicas y el Ararteko", Seminario sobre Derecho Parlamentario, Parlamento Vasco, Vitoria, 1990, págs. 319 a 363.

Bonet Navarro, A.: Procesos ante el Justicia de Aragón, Guara, Zaragoza, 1982.

Bonet Navarro, A.: El Justicia de Aragón: historia y derecho. Breve estudio introductorio, Cortes de Aragón, Zaragoza, 1995.

Cano Bueso, J.: El Defensor del Pueblo Andaluz: génesis y contenido de la Institución, Defensor del Pueblo Andaluz, Sevilla, 1986.

CaÑellas i Balcells, A.: "El Sindic de Greuges de Catalunya: Procedimiento y criterios de actuación", El trabajo y la práctica de los defensores del pueblo $y$ las instituciones nacionales de derechos humanos, Ministerio de Relaciones Exteriores, Copenhage, págs. 111 a 122.

CARBAllo Armas, P.: "La importancia de los medios informales del Ombudsman en las resoluciones de problemas. La labor del Diputado del Común", Revista de Ciencias Jurídicas, n. ${ }^{\circ}$ 2, 1997, págs. 105 a 111.

Carballo Armas, P.: El Diputado del Común de Canarias: la configuración institucional del Ombudsman en el Estatuto de autonomía de Canarias, Universidad de las Palmas de Gran Canaria, Las Palmas, 2000.

Carrascosa López, V.: "El Defensor del Pueblo extremeño", Estatuto de Autonomía de Extremadura, (2 vols.), Universidad Nacional de Educación a Distancia, Mérida, 1985, págs. 57 a 91.

Carro Fernández-Valmayor, J.L.: "Las relaciones entre el Defensor del Pueblo y las figuras autonómicas afines. Una propuesta de reflexión", Revista de Estudios de la Administración Local y Autonómica, n. ${ }^{\circ}$ 243, 1989, págs. 527 a 544 .

Cazorla Pérez, J., Cano Bueso, J.: "Los defensores del pueblo: imagen pública e interrelaciones jurídicas", Revista de Estudios Políticos, n. ${ }^{\circ}$ 59, 1988, págs. 27 a 47.

Climent González, C.: "El Síndico de Agravios de la Comunidad Valenciana", Boletín de Información del Ministerio de Justicia, n. ${ }^{\circ} 1361,1984$, págs. 3 a 8.

Cobiella Cuevas, L.: Juan Canario, los derechos humanos y el Diputado del Común, Centro de la Cultura Popular Canaria, La Palma, 1993.

Conde Pumpido Ferreiro, M.: "La relación entre los Ombudsmen nacionales, regionales y locales", Tercera Conferencia Europea del Ombudsman regional, Ararteko, Vitoria, 1993, págs. 91 a 112.

Cora Rodríguez, J.: "Institución del Valedor do Pobo. Un año de actuación", Revista Xurídica Galega, n. ${ }^{\circ}$ 1, 1992, págs. 343 a 352.

Corchete Martín, M.J.: «Propuesta de reforma en las relaciones Defensor del Pueblo - comisionados parlamentarios autonómicos", Revista Vasca de Administración Pública, n. ${ }^{\circ}$ 56, 2000, págs. 163 a 197.

Corchete Martín, M.J.: "El Procurador del Común", Derecho Público de Castilla y León, I. SÁez Hidalgo, Lex Nova, Valladolid, 2008, págs. 605 a 621. 
Chamizo de la Rubia, J.: "Aportaciones del Defensor del Pueblo Andaluz para la incorporación de los derechos sociales al Estatuto de Autonomía para Andalucía", Nuevas Politicas Públicas, n. ${ }^{\circ} 2$, Los derechos sociales, Instituto Andaluz de Administración Pública, Sevilla, 2006.

Chamizo de la Rubia, J.: "Defensor del Pueblo Andaluz", Aproxima: Justicia y Administración Pública, n. ${ }^{\circ}$ 10, 2007, págs. 6 a 9.

Delgado Pérez, I.: "Los informes especiales del Defensor del Pueblo Andaluz como expresión de su capacidad para emprender actuaciones de oficio", Justicia. Servicio Público, n 4, 2004, págs. 36 a 39.

Díez Bueso, L.: "Propuesta de configuración estatutaria del Síndic de Greuges de Cataluña", Jornadas sobre reformas estatutarias, derechos sociales y defensores del pueblo autonómicos, VV.AA., Servicio de Publicaciones del Defensor del Pueblo Andaluz, Sevilla, 2006.

Díez Bueso, L.: "Los servicios sociales de atención a la tercera edad: el Defensor del Pueblo estatal y diversos defensores del pueblo autonómico", Los servicios sociales de atención a la tercera edad: el caso de Cataluña, Tirant lo Blanch, Valencia, 2002, págs. 363 a 378.

Díez Bueso, L.: Los defensores del pueblo (ombudsmen) de las Comunidades Autónomas, Senado, Madrid, 1999.

Díez Bueso, L.: "El modelo de Ombudsman autonómico y su reflejo en la tramitación de quejas", Revista Vasca de Administración Pública, n. ${ }^{\circ} 53$, 1999, págs. 11 a 30.

Díez Bueso, L.: Los "Ombudsmen" de las Comunidades Autónomas, Universitat de Barcelona, Barcelona, 1998.

Díez Bueso, L.: "El Síndic de Greuges de Cataluña", Autonomíes. Revista Catalana de Derecho Público, n. ${ }^{\circ}$ 19, 1994, págs. 25 a 51.

DíAz Revorio, F.J.: "Antecedentes y perspectivas para un Defensor del Pueblo en Castilla-La Mancha", Parlamento y Constitución, n. ' 1, 1997, págs. 189 a 200.

Domingo Jiménez JaÉn, A., García Mahamut, R.: "Las figuras similares al Defensor del Pueblo en las Comunidades Autónomas: el Diputado del Común", Estudios de derecho público en homenaje a Juan José Ruiz-Rico, 1997, págs. 949 a 966.

EMBid Irujo, A.: El control de la Administración Pública por los comisionados parlamentarios autonómicos, Instituto Nacional de Administración Pública, Madrid, 1991.

EMBID Irujo, A.: "Los comisionados parlamentarios autonómicos y el control de la Administración Local", Revista de Estudios de la Administración Local y Autonómica, n. ${ }^{\circ}$ 238, 1988, págs. 1101 a 1122.

Eguiguren Imaz, J.: "El Ararteko o Defensor del Pueblo Vasco", Revista de Estudios Políticos, n. ${ }^{\circ} 46-47,1985$, págs. 585 a 607.

EmBid IRujo, A.: El control de la Administración Pública por los comisionados parlamentarios autonómicos, Instituto Nacional de Administración Pública, Madrid, 1988.

Enériz OlaecheA, F.J.: "El Defensor del Pueblo de la Comunidad Foral de Navarra", Revista Jurídica de Navarra, n. ${ }^{\circ}$ 42, 2006, págs. 9 a 54. 
Enériz Olaechea, F.J.: «La posición institucional del Defensor del Pueblo de Navarra", La Institución del Defensor del Pueblo de Navarra, Institución del Defensor del Pueblo de la Comunidad Foral de Navarra, 2008, págs. 31 a 94.

Feltrer RAmBAud, L.: “Tramitación de quejas y colaboración con figuras autonómicas", El fortalecimiento del ombudsman iberoamericano, Universidad de Alcalá, Alcalá de Henares, 1999, págs. 109 a 119.

Figueroa Laraudogoitia, A. "El Ararteko: análisis del primer quinquenio de funcionamiento", Autonomies. Revista Catalana de Derecho Püblico, n. ${ }^{\circ}$ 19, 1994, págs. 53 a 74.

Figueroa LARAUdDGoitia, A. «El Ararteko: regulación y perspectivas de la figura en el ordenamiento autonómico vasco", Anuario de jornadas: 19891990, Instituto Vasco de Administración Pública, Oñati, 1991, págs. 87 a 105.

Figueruelo Burrieza, A.: "La institución del Procurador del Común", Revista jurídica de Castilla y León, n. ${ }^{\circ}$ extra 1, 2004, págs. 371 a 394.

Folchi i Bonafonte, I., Bayona i Rocamora, A., "La defensa de los derechos fundamentales y de las libertades públicas en el ámbito de las Comunidades Autónomas. Instituciones similares a la del Defensor del Pueblo", Revista Vasca de Administración Pública, n. ${ }^{\circ}$ 6, 1983, págs. 73 a 119.

Galán Lorda, M; De la Iglesia Chamarro, A; Salvador Armendáriz, A : El Defensor del Pueblo de la Comunidad Foral de Navarra: análisis de la Ley foral 4/2000, de 3 de julio: antecedentes históricos y régimen jurídico de la institución, Pamplona, Institución del Defensor del Pueblo de la Comunidad Foral de Navarra, Universidad de Navarra, 2004

García ÁlvVAREZ, M.: «El control de la Administración local por los comisionados parlamentarios autonómicos", XI Jornadas de coordinación entre defensores del pueblo, VV.AA., Servicio de Publicaciones del Procurador del Común. León, 1997.

García Álvarez, M.: "Procurador del Común y extranjería", XVI Jornadas de Coordinación Defensores del Pueblo, Senado, Madrid, 2001, págs. 205 a 215.

García Álvarez, M.: "La integración de los inmigrantes en la Comunidad de Castilla y León: La experiencia del Procurador del Común", XVII Jornadas de Coordinación de Defensores del Pueblo, Pamplona, 2003, págs. 201 a 222.

García Atanes, F.: «El papel de internet y de las tecnologías como factor de coordinación para la mejora de los servicios de las defensorías", $X V I$ Jornadas de Coordinación Defensores del Pueblo, Palacio del Senado, Madrid, 2002, págs. 107 a 116.

García RocA, J.: "El Defensor del Pueblo en las Comunidades Autónomas", Revista de la Facultad de Derecho de la Universidad de Granada n. ${ }^{\circ}$ 14, 1987, págs. 167 a 215.

García Mahamut, R., JimÉnez JaÉn, A.: "Las figuras similares al Defensor del Pueblo en las Comunidades Autónomas: el Diputado del Común", Estudios de Derecho Público, Tecnos, Madrid, 1997, págs. 949 a 964. 
GarCía Vicente, F.: «Una experiencia de colaboración con las administraciones públicas aragonesas: el proceso de implantación territorial del Justicia de Aragón", XIII Jornadas de Coordinación entre Defensores del Pueblo, Diputado del Común, Gran Canaria, 1999, págs. 227 a 236.

GARRIDO LÓPEZ, C.: "Fundamento y virtualidad de los acuerdos de cooperación entre el Defensor del pueblo y los Comisionados parlamentarios autonómicos", Derechos constitucionales y pluralidad de ordenamientos, M.A. Aparicio Pérez (Coord.), Cedecs, Barcelona, 2001, págs. 601 a 616.

GARRIDO LÓPEZ, C.: «El Justicia de Aragón: naturaleza, estatuto jurídico y funciones", Derecho público aragonés, A. Embid Irujo (Dir.), Dykinson, Madrid, 2000, págs. 203 a 260.

Gastón, E.: "El Justicia de Aragón: análisis de una experiencia", Anuario de jornadas: 1989-1990, Instituto Vasco de Administración Pública, Oñati, 1991, págs. 147 a 160.

Gil-Robles y Gil-Delgado, A.: «El Defensor del Pueblo, el Síndic de Greuges y los comisionados autonómicos", 10 anys de jurisprudencia del Tribunal Constitucional, Parlament, Palma de Mallorca, 1993.

Gil-Robles y Gil-Delgado, A.: El Defensor del Pueblo e instituciones similares de ámbito territorial reducido", Revista de la Facultad de Derecho de la Universidad Complutense, n. ${ }^{\circ} 4,1981$, págs. 27 a 51.

GiNé I DAVÍ, J.: «La Ley 36/1985, de 6 de noviembre, por la que se regulan las relaciones entre el Defensor del Pueblo y las figuras similares en las diversas Comunidades Autónomas", Autonomies: Revista Catalana de Derecho Público, n. ${ }^{\circ}$ 4, 1986, págs. 109 a 126.

González-Ares Fernández, J.A.: "El Valedor do Pobo. Ombudsman de la Comuniadad de Galicia", La Ley, n. ${ }^{\circ}$ 1601, 2003.

González-Ares Fernández, J.A.: El Valedor do Pobo: del Ombusdman sueco al comisionado parlamentario gallego, Tirant Lo Blanch, Valencia, 2005.

González Casanova, J.A.: "El Sindic de Greuges", Comentaris sobre l'Estatut d'Autonomía de Catalunya, Vol. III, Institut d’Autonomía de Catalunya, Institut d’Estudis Autonomics, 1988, págs. 295 a 305.

Guevara SaleTA, J.R.: «Discurso de inauguración de la Jornada de Estudio sobre el Ararteko", Anuario de Jornadas 1989-1990, Instituto Vasco de Administración Pública, Oñati, 1991, págs. 81 a 86.

Iglesia Chamarro, A. de la: "Antecedentes del Defensor del Pueblo de la Comunidad Foral de Navarra", El Defensor del Pueblo de Navarra, A. PÉrez Calvo (Coord.), Instituto Navarro de Administración Pública, 2009, págs. 75 a 102.

Justicia de ARAgón.: El nuevo justiziazgo: 1988-1993: análisis de un quinquenio, Justicia de Aragón, Zaragoza, 1993.

Kortadi, E., San Martin, J., Söderman, J.: La Institución del Ombudsman en el País vasco y Finlandia, Eusko Ikaskuntza, Donista, 1992.

Langa Rocha, I.: "Informes del Ararteko y Defensor del Pueblo 1992, aspectos relevantes para la Ertzaintza", Revista Técnica del Ertzaina, n. ${ }^{\circ}$ 8, 1994, págs. 104 a 119. 
LaSARTE, C.: "Comentario al artículo 46", S. MuÑoz Machado (Dir.), Comentarios al Estatuto de Autonomía de la Comunidad Autónoma de Andalucía, Instituto de Estudios de Administración Local, Madrid, 1987, págs. 652 a 657.

Leguina Villa, J.A.: “Dictamen sobre la constitucionalidad, cuestionada por el Defensor del Pueblo, de determinados preceptos de la Ley catalana de Política Lingüística", Revista de administración pública, n. ${ }^{\circ}$ 153, 2000, págs. 539 a 558.

LIZÓN GINER, A.: "Medio ambiente, urbano, ruido y actividades molestas", Gabinete de Estudios del Sindic de Greuges (Ed.), IX Jornadas de Coordinación entre Defensores del Pueblo, Sindic de Greuges, Alicante, 1995, págs. 15 a 84 .

López-Medel Bascones, J.: "Los defensores del pueblo autonómicos", Revista de las Cortes Generales, n. ${ }^{\circ}$ 55, 2002, págs. 151 a 163.

lópez Basaguren, A. Maestro Buelga, G.: El Ararteko, Instituto Vasco de Administración Pública, Oñati, 1993.

lópez Basaguren, A. Maestro Buelga, G.: El Ararteko, Instituto Vasco de Administración Pública, Oñati, 1985.

López BASAguRen, A.: "Los derechos fundamentales en el ordenamiento autonómico del País Vasco", Revista de Estudios Políticos, n. ${ }^{\circ}$ 46/47, 1985, págs. 111 a 147.

López Basaguren, A.: "Las relaciones entre el Defensor del Pueblo y las figuras similares de las Comunidades Autónomas. Su regulación en la Ley 36/1985", Revista Vasca de Administración Pública n. ${ }^{\circ}$ 14, 1986, págs. 251 a 259 .

Lumbierres Subías, M.C.: «El Defensor del Pueblo Estatal y los Defensores Autonómicos: El alcance de su colaboración", Anuario del Centro de la Universidad Nacional de Educación a Distancia de Barbastro, n. ${ }^{\circ} 14$, 2001, págs. 321 a 340.

LumBierRes Subías, M.C.: El nuevo Justicia y la protección autonómica de los ciudadanos en Aragón, El Justicia de Aragón, Zaragoza, 2006.

Luque Sevilla, L.: El Defensor del Pueblo Andaluz, Instituto de Estudios de Administración Local, Granada, 1984.

MAeztu GRegorio De Tejada, J.: "Medio ambiente urbano (ruidos y actividades molestas). Balance de la experiencia y actuaciones del Defensor del Pueblo andaluz ante la problemática", Gabinete de Estudios del Sindic de Greuges, IX Jornadas de coordinación entre Defensores del Pueblo, Sindic de Greuges, Alicante, 1995, págs. 97 a 124.

Magro Servet, V.: "La delimitación competencial entre el Defensor del Pueblo, los comisionados parlamentarios de las CC.AA. y los órganos del Poder Judicial", Revista del poder judicial, n. ${ }^{\circ}$ 56, 1999, págs. 231 a 250.

Magro Servet, V.: "La delimitación competencial entre el Defensor del Pueblo, los comisionados parlamentarios de las Comunidades Autónomas y los órganos del poder judicial", La Ley: Revista jurídica española de doctrina, jurisprudencia y bibliografía, n. ${ }^{\circ} 4665,1998$, págs. 1 a 5.

Martínez Alarcón, M.L.: El Defensor del Pueblo de Castilla-La Mancha en la 
teoría y en la práctica, Ediciones Parlamentarias de Castilla-La Mancha, 2005.

MarruRi Uriarte, A. Gutiérrez Bañares, S.: “Crónica de la III Jornada de Estudio sobre El Ararteko", Revista Vasca de Administración Pública, n. . 24, 1989, págs. 261 a 268.

Mas i Solench, J.M.: El Síndic de Grenges de Catalunya, Síndic de Greuges de Catalunya, Barcelona, 1995.

MEDINA, R.: “El Síndico de Agravios: consideraciones sobre la utilidad de la institución", Revista Valenciana d’Estudis Autonómics, n. ${ }^{\circ}$ 3, 1985, págs. 185 a 191.

Montesinos SÁnchez, M.N.: “Comentario a la resolución del Síndico de Agravios de la Comunidad Valenciana a la queja n. ${ }^{\circ}$ 960794: patrimonio histórico-libertad religiosa en la Administración", Estudios en homenaje al profesor Martinez Valls, Universidad de Alicante, Alicante, 2000, págs. 475 a 497.

MonTESINOS SÁNCHEZ, M.N.: "Defensor del pueblo y derechos fundamentales: la libertad religiosa en la Administración", Revista General de Derecho, n. ${ }^{\circ}$ 637-638, 1997, págs. 12141 a 12164.

Montesinos SÁnchez, M.N.: "Las actuaciones del Defensor del Pueblo y de los comisionados autonómicos en materia de libertad religiosa y de conciencia y sus conexiones", La libertad religiosa y de conciencia ante la justicia constitucional, J. Martínez-Torrón (Coord.), Comares, Granada, 1998, págs. 669 a 685.

Morillo-Velarde Pérez, J.I.: "El Defensor del Pueblo andaluz", Autonomies. Revista Catalana de Derecho Público, n. ${ }^{\circ} 19$, 1994, págs. 75 a 94.

Morillo-Velarde Pérez, J.I.: «El Defensor del Pueblo andaluz. Cinco años de existencia", Administración de Andalucía, n. ${ }^{\circ}$ 1, 1990, págs. 215 a 224.

Múgica Herzog, E.: "El Defensor del Pueblo y sus relaciones con las figuras análogas de las Comunidades Autónomas", La España de las autonomías: reflexiones 25 años después, M. Balado Ruiz-Gallegos (Dir.), Bosch, Barcelona, 2005, págs. 191 a 202.

MuÑoz Arnau, J.A.: «El Defensor del Pueblo de la Comunidad Autónoma de La Rioja", Derecho Público de la Comunidad Autónoma de La Rioja, R.L. Chueca Rodríguez, A. Fanlo loras, M.A. Pascual Medrano (Coords.), Aranzadi, Navarra, 2007, págs. 89 a 103.

Murillo García-Atance, I.: "El Justicia de Aragón: Algunas cuestiones pendientes", Revista Aragonesa de Administración Pública, n. ${ }^{\circ}$ 20, 2002, págs. 117 a 163.

Obra Sierra, S. de la: "El Defensor del Pueblo Andaluz y las bibliotecas municipales: comentarios (parciales) para una crónica", Boletín de la Asociación Andaluza de Bibliotecarios, n. ${ }^{\circ}$ 75-76, 2004, págs. 85 a 95.

Oenhing Ruiz, H.: "El Defensor del Pueblo: Algunos problemas en su adaptación orgánico-funcional", Revista de Estudios Políticos, n. ${ }^{\circ}$ 72, 1991, págs. 89 a 128.

Pérez Calvo, A.: (Coord.), El Defensor del Pueblo de Navarra, Instituto Navarro de Administración Pública, 2009. 
Pérez Calvo, A.: "El Defensor del Pueblo”, El Defensor del Pueblo de Navarra, A. Pérez Calvo (Coord.), Instituto Navarro de Administración Pública, Pamplona, 2009, págs. 35 a 71.

Pérez Calvo, A.: "Autonomía y funciones de los Comisionados parlamentarios en España", Retos actuales de las instituciones nacionales de protección y promoción de los Derechos humanos (A diez años de los principios de París), México, 2004, págs. 107 a 128.

Pérez Calvo, A.: "La defensa de los derechos constitucionales de los ciudadanos por los comisionados parlamentarios. Actualidad y perspectivas", Jornadas sobre el Defensor del Pueblo Andaluz, G. RuIz RICO (Ed.), UNIA - Defensor del Pueblo Andaluz, Baeza, 2001, págs. 31 a 50.

Pérez Calvo, A.: "Defensor del pueblo y comisionado parlamentario vasco", Primeras Jornadas de Estudio del Estatuto de Autonomía del País Vasco, Vol. 3, 1983, págs. 1475 a 1518.

Pérez Calvo, A.: "Defensor del pueblo y comisionado parlamentario vasco", Revista Vasca de Administración Pública, n. ㄱ 3, 1982, págs. 31 a 56.

Pérez LuÑo, A. E.: "El Defensor del Pueblo de Andalucía", J. Pérez Royo, A.J. Porras Nadales (Eds.), El Parlamento de Andalucía. Análisis de la Primera Legislatura (1982/1986), Tecnos, Madrid, 1987, págs. 297 a 334.

Pitarch, I.: "Estructura i funcions de l'Ombudsman al dret comparat. Propostes per a la Generalitat", Administración Pública, 1978, n. ${ }^{\circ}$ 1, págs. 129 a 172.

Pomed, L.: "El Justicia de Aragón. Defensor del Estatuto de Autonomía", Revista Aragonesa de Administración Pública, n. ${ }^{\circ}$ 22, 2003, págs, 211 a 230.

PorRas NADAles, A.: "La posición estatutaria del Defensor del Pueblo Andaluz", VV.AA, Jornadas sobre el Defensor del Pueblo Andaluz, Servicio de Publicaciones del Defensor del Pueblo Andaluz, Sevilla, 2002.

Porras Nadales, A.: «Los defensores del pueblo ante la reforma de los Estatutos de Autonomía: el Ombudman frente a los derechos sociales", Jornadas sobre reformas estatutarias, derechos sociales y defensores del pueblo autonómicos, Servicio de Publicaciones del Defensor del Pueblo Andaluz, Sevilla, 2006.

Rahola, F.: «Exposición del Síndic de Greuges para la III Jornada de Estudio sobre el Ararteko", Anuario de jornadas: 1989-1990, Instituto Vasco de Administración Pública, Oñati, 1991, págs. 133 a 145.

Retuerto Buades, M.: "Ambito propio del Defensor del Pueblo y relaciones de coordinación y cooperación en los Organos similares de las Comunidades Autónomas", El Procurador del Común: Defensor del pueblo y Comunidades Autónomas, Valladolid, 1995, págs. 95 a 114.

Roca Roca, E.: "El Defensor del Pueblo en las Comunidades Autónomas", Revista de la Facultad de Derecho de la Universidad de Granada, n. ${ }^{\circ} 14$, 1987, págs. 167 a 216.

RodríGuez Molina, J.: El personero: portavoz y defensor de la comunidad ciudadana, Diputación Provincial de Jaén, Jaén, 2003.

Rosal Blasco, B. Del: «Propuestas institucionales sobre la configuración estatutaria de los defensores del pueblo autonómicos desde la experiencia de 
la institución del Sindic de Greuges de la Comunidad valenciana", II Jornadas sobre reformas estatutarias, derechos sociales y defensores del pueblo autonómicos, Defensor del Pueblo Andaluz, Sevilla, 2006, págs. 109 a 120.

Ruiz-Rico Ruiz, G.J.: "Los defensores del pueblo autonómicos tras la reforma de los estatutos de autonomía", Revista d'estudis autonòmics i federals, $\mathrm{n} .{ }^{\circ}$ 6, 2008, págs. 365 a 395.

Ruiz-Rico Ruiz, G.J.: "El Defensor del Pueblo Andaluz", Estatuto de Autonomía de Andalucía. Estudio sistemático, Ariel, Barcelona, 1990, págs. 195 a 212.

Ruiz Robledo, A.: "Cuatro divagaciones sobre el Defensor del Pueblo Andaluz", Administración de Andalucía: Revista Andaluza de Administración Pública, n. ${ }^{\circ}$ Extra 1, 2003, págs. 213 a 238.

Salanova AlCalde, R.: "El Justicia de Aragón", La Comunidad Autónoma de Aragón (instituciones políticas y administrativas), IberCaja, Zaragoza, 1990, págs. 201 a 227

San Martín Ortiz De Zárate, J.: "Fundamentos de la institución del Ararteko", Revista Internacional de los Estudios Vascos, n. ${ }^{\circ} 1,1995$, págs. 65 a 76.

San Martín Ortiz de Zarate, J.: "Dos años de experiencia del primer Ombudsman del País Vasco", VV.AA, La institución del ombudsman en el País Vasco y Finlandia, San Sebastián, 1992, págs. 23 a 36.

San Martín, J.: "Agurra", Anuario de Jornadas 1989-1990, Servicio de Estudios del IVAP. Instituto Vasco de Administración Pública, Oñate, 1991, págs. 127 a 131.

SAn MARTín, J.: Dichos y hechos (Esanak eta eginak), Ararteko, Vitoria-Gasteiz, 1994.

San Martín, J.:"Dos años de experiencia del primer Ombusdman del País Vasco", Cuadernos de Sección. Derecho n. ${ }^{\circ}$ 7, 1992, págs. 23 a 35.

SAN MARTín, J.: "Fundamentos de la Institución del Ararteko", Revista Internacional de los Estudios Vascos, n. ${ }^{\circ} 1,1995$, págs. 65 a 76.

San Martín Ortiz de Zarate, J.: "La importancia del Ombudsman regional", Tercera Conferencia Europea del Ombudsman: La importancia del Ombudsman regional, Ararteko, Vitoria, 1993, págs. 69 a 78.

SÁnchez Bursón, J.M.: "La tutela a la salud desde la institución del Defensor del Pueblo Andaluz", Administración de Andalucía, n. ${ }^{\circ} 22$, 1995, págs. 189 a 217.

SÁnchez FerRIZ, R.: «El Sindic de Greuges. Consideraciones sobre la significación actual de una institución necesaria para la efectividad de los derechos y libertades", Corts. Anuario de Derecho Parlamentario, n. ${ }^{\circ}$ 5, 1998, págs. 23 a 46.

SARMIENTO MÉNDEZ, X.: “O Ombudsman de Galicia: regulación xurídico institucional do órgano previsto no artigo 14 do Estatuto de Autonomía para Galicia", Dereito. Revista Xurídica da Universidade de Santiago, Vol. 11, n. ${ }^{\circ} 1,2002$, págs. 241 a 271 ,

Tovar Santos, F.: «Escuela de ciudadanía: la actividad del Diputado del Común de Canarias. Una experiencia regional", Tercera conferencia europea del 
Ombudsman. La importancia del Ombudsman regional, Ararteko, Vitoria, 1993, pág. 1866 a 188.

VArela SuANzes-Carpegna, J.: "Los Ombusdman regionales en el ordenamiento jurídico español: su ámbito objetivo de competencias", Los procesos de formación de las Comunidades Autónomas. Aspectos jurídicos y perspectivas políticas, Granada, 1984, págs. 677 a 699.

Vera Padial, M.: "Notas sobre la adaptación del Ombusdman a los ordenamientos de las Comunidades Autónomas", Autonomies. Revista Catalana de Dret Públic, n. ${ }^{\circ}$ 19, 1994), págs. 9 a 22.

Vera Santos, J.M.: El Defensor del Pueblo en la Constitución y en los Estatutos de Autonomía, Centro de Estudios Políticos y Constitucionales, Madrid, 2002.

Vintró i Castells, J., Bayona, A.: “El Consell de Garanties Estatutaries, el Sindic de Greuges, la Sindicatura de Comptes i el Consell de l'Audiovisual de Catalunya", Dret Public de Catalunya, Atelier, Barcelona, 2008, págs. 353 a 408.

Visiedo Mazón, F.J.: «El Defensor del Pueblo en el ámbito de las Comunidades Autónomas: principales problemas que se plantean", Las Cortes Generales, Vol. III, Instituto de Estudios Fiscales, Madrid, 1987, págs. 2297 a 2318.

Visiedo Mazón, F.J.: «El Defensor del Pueblo: Instituciones similares en el ámbito de las Comunidades Autónomas", Congreso Nacional de Ciencia Politica, n. ${ }^{\circ}$ 4, 1984, Universidad de Alicante, Alicante, 1980.

VV.AA.: VII Jornadas de coordinación entre Defensores del Pueblo, Defensor del Pueblo, Madrid, 1993.

VV.AA.: Jornadas de coordinación entre Defensores del Pueblo, Síndic de Greuges, Barcelona, 1996.

VV.AA.: XI Jornadas de coordinación entre defensores del pueblo, Servicio de Publicaciones del Procurador del Común. León, 1997.

Yubero Martínez, T.: "El Justicia de Aragón: sus funciones jurisdiccionales", Revista de la Facultad de Derecho de la Universidad Complutense, n. ${ }^{\circ}$ 74, 1988-89, págs. 769 a 782.

Zárate y Pedraza de Ayala, B.: «El Sistema de Control de la Actividad Administrativa de la Junta de Andalucía en el informe del Parlamento del Defensor del Pueblo Andaluz del año 2001, de Andalucía", Revista Andaluza de Administración Pública, n. ${ }^{\circ}$ 49, 2003, págs. 289 a 295.

\section{DEFENSOR DEL PUEBLO EUROPEO}

Alonso De Antonio, J.A.: "Algunas consideraciones sobre el Defensor del Pueblo Europeo", Constitución española en el ordenamiento comunitario europeo (II): XVII jornadas de estudio, Vol. 2, Ministerio de Justicia, Madrid, 1998, págs. 1519 a 1538.

Alonso De Antonio, J.A.: "Algunas consideraciones sobre el Defensor del Pueblo europeo", Revista de la Facultad de Derecho de la Universidad Complutense, n. ${ }^{\circ}$ 84, 1993-1994, págs. 23 a 40. 
Arenas Meza, M.: "Algunas reflexiones en torno al papel del Defensor del Pueblo Europeo en la protección de los derechos fundamentales de los ciudadanos de la Unión Europea", La Unión Europea ante el siglo XXI: los retos de Niza, C. Escobar Hernández, C.: (Coord.), Boletín Oficial del Estado - Universidad de Cantabria, Santander, 2003, págs. 67 a 75.

Astarloa Huarte-Mendicoa, I.: «El estatuto del Defensor del Pueblo, El Defensor del Pueblo en el Tratado de la Unión European: Jornadas celebradas los días 2 y 3 de noviembre de 1992, en la Sede de la Universidad en Getafe, 1993, págs. 155 a 200.

Astarloa Villena, F.: "El Defensor del Pueblo en el Tratado de Maastricht", Revista de la Facultad de Derecho de la Universidad Complutense, n. ${ }^{\circ}$ 18, 1994, págs. 105 a 110.

Baldira Munte, F.: “El Defensor del Pueblo Europeo”, Boletín de los Colegios de Abogados de Aragón, n. ${ }^{\circ}$ 132, 1994.

Carmona y Choussat, J.F.: El Defensor del Pueblo Europeo, Instituto Nacional de Administración Pública, Madrid, 2000.

Cendoya Mendez de Vigo, J.F.: «El Defensor del Pueblo Europeo", Boletín de Información del Ministerio de Justicia e Interior, n. ${ }^{\circ}$ 1739, 1995, págs. 157 a 170.

Cobreros Mendazona, E.: “Responsabilidad patrimonial del Defensor del Pueblo Europeo?", Revista de Administración Pública, n. ${ }^{\circ}$ 159, 2002, págs. 209 a 220.

Ferrer Jefrrey, B.: «Presente y futuro del Defensor del Pueblo Europeo, Guardián de la buena Administración", Revista de Derecho de la Unión Europea, n. ${ }^{\circ}$ 3, 2002, págs. 341 a 353.

García Soriano, M.V.: "La protección de los derechos y las libertades del individuo como objetivo prioritario del Defensor del Pueblo Europeo", Revista Europea de Derechos Fundamentales, n. ${ }^{\circ}$ 5, 2005, págs. 117 a 144.

GARCÍA VicENTE, F.: «Instrumentos supranacionales reguladores de figuras defensoriales: Unión Europea, Consejo de Europa, institutos especializados", Jornadas de coordinación entre Defensores del Pueblo, Defensor del Pueblo, Madrid, 2002, págs. 25 a 58.

Gil-Robles y Gil-Delgado, A.: «El Defensor del Pueblo Europeo: de la utopía a la esperanza", Los derechos del europeo, Incipit, Madrid, 1993, págs. 223 a 238.

González Alonso, L.N.: "El Defensor del Pueblo Europeo", Carta de los derechos fundamentales de la Unión Europea, A. MANGAS MARTín, L.N. GONZÁlez Alonso (Coords.), Fundación BBVA, Bilbao, 2008, págs. 700 a 711.

GonZÁlez-Varas IbáÑEz, A.: «El Defensor del Pueblo Europeo y los conflictos competenciales con las instituciones afines", Revista galega de administración pública, n. ${ }^{\circ} 31,2002$, págs. 203 a 224.

Hoyo Rodrigo, J.: "Defensor del Pueblo Europeo", Comentarios a la Constitución Europea, Garrido Mayol, V., García Couso, S., Álvarez Conde, E., (Coords.) Vol. 1, Tirant lo Blanch, Valencia, 2004, págs. 1295 a 1315.

IBÁÑEZ GARCía, I.: "Los votos particulares en el proceso judicial comunitario; el contenido mínimo del derecho de petición ante el Parlamento Europeo y la protección de este derecho por el Defensor del Pueblo", Noticias de la Unión Europea, n. ${ }^{\circ}$ 156, 1998, págs. 25 a 36. 
Moreiro González, C.J.: «El Defensor del Pueblo en el Tratado de la Unión Europea", Gaceta Jurídica de la CEE, n. ${ }^{\circ} 119,1993$, págs. 167 a 259.

Palomares Amat, M.: «El Defensor del Pueblo Europeo", Noticias de la Unión Europea, n. ${ }^{\circ} 173,1999$, págs. 53 a 64.

Palomares Amat, M.: «El reconocimiento, con carácter hipotético y excepcional, de la responsabilidad extracontractual de la Comunidad Europea por los daños causados por el Defensor del Pueblo Europeo en el ejercicio de sus funciones: comentario a la sentencia del TJCE de 23 de marzo de 2004, Defensor del Pueblo c. Frank Lamberts, asunto C-234/02P", Revista General de Derecho Europeo, n. ${ }^{\circ}$ 5, 2004.

Retuerto Buades, M.: «Emigración, Derechos Humanos de los Extranjeros, especialmente de los refugiados, desde el Defensor del Pueblo", Eguzkilore: Cuaderno del Instituto Vasco de Criminología, n. ${ }^{\circ}$ Extra 8, 1995, págs. 55 a 68.

Retuerto Buades, M.: «El Defensor del Pueblo, institución de garantía no jurisdiccional del Derecho Nacional y Comunitario", Revista de las Cortes Generales, n. ${ }^{\circ} 29,1993$, págs. 7 a 20.

Rovira ViÑas, A.: "Los Defensores del Pueblo y la Convención de Prüm", Revista de Derecho Constitucional Europeo, n. ${ }^{\circ}$ 7, págs. 207 a 233.

Ruiz Francés, A.: "El Defensor del Pueblo de la Unión Europea", Cuadernos europeos de Deusto, n. ${ }^{\circ} 17,1997$, págs. 93 a 122.

Sainz De Rozas Bedialauneta, R.: “El Ararteko ante la aplicación del Protocolo Facultativo de la Convención contra la Tortura y Otros Tratos o Penas Crueles, Inhumanos o Degradantes", La creación del mecanismo español de prevención de la tortura, Iustel, Madrid, 2009, págs. 325 a 336.

SALIDO VAlLe, C.: "El tratamiento de los menores extranjeros no acompañados, según las recomendaciones del Defensor del Pueblo", Anuario de justicia de menores, n. ${ }^{\circ}$ 6, 2006, págs. 165 a 186.

SÁnChez BuRsón, J.M.: "La tutela a la salud desde la institución del Defensor del Pueblo Andaluz", Administración de Andalucía: revista andaluza de administración pública, n. ${ }^{\circ} 22,1995$, págs. 189 a 217.

SÁnchez López, J.: "El Defensor del Pueblo Europeo", Revista de derecho constitucional europeo, n. ${ }^{\circ}$ 3, 2005, págs. 183 a 194.

San Martín Ortiz De Zárate, J.: Dichos y hechos, Ararteko, Vitoria, 1994.

San Martín Ortiz de Zarate, J.: "Dos años de experiencia del primer Ombudsman del País Vasco" Edorta KorTadi (et alli), La institución del ombudsman en el País Vasco y Finlandia, Donostia : Eusko Ikaskuntza. Sociedad de Estudios Vascos, D.L. 1992, págs. 23 a 36

Söderman, J.M.: "El Defensor del Pueblo como garante en el sistema comunitario de defensa de los derechos ciudadanos", El fortalecimiento del Ombudsman iberoamericano, 1999, págs. 11 a 22.

Ull PONT, E.: "Un Defensor del Pueblo para la Comunidad Europea", La constitución española en el ordenamiento comunitario europeo (I): XVI jornadas de estudio, Vol. 2, 1995, págs. 1943 a 1972. 


\section{DOCUMENTOS E INFORMES}

Capdevila Capdevila, M.: "Centros de protección de menores con trastornos de conducta y en situación de dificultad social: informe del Defensor del Pueblo, febrero 2009", Educación social: Revista de intervención socioeducativa, n. ${ }^{\circ} 41,2009$, págs. 8 a 11.

Préstamo, J.: "Protección de edificios históricos: El Defensor del Pueblo", Seguritecnia: Revista Decana Independiente de Seguridad, n. ${ }^{\circ}$ 359, 2009, págs. 126 a 127.

Retuerto Buades, M.: "La experiencia del Defensor del Pueblo y la contaminación acústica", IX Jornadas de Coordinación entre Defensores del Pueblo, Sindic de Greuges, Valencia, 1995, págs. 85 a 95.

Sarasíbar Marco, C.: "Las resoluciones del Defensor del Pueblo de la Comunidad Foral de Navarra", El Defensor del Pueblo de Navarra, A. PÉREz Calvo (Coord.), Instituto Navarro de Administración Pública, 2009, págs. 235 a 271.

Trillo Alvarez, J.: "Violencia escolar entre iguales: Informe del Defensor del Pueblo", La convivencia en las aulas: problemas y soluciones, A. MORENO GonZÁlez, M.P. Soler Villalobos (Coords.), 2006, págs. 101 a 114.

Uribarri Murillo, A.: "Residuos y vertederos. La experiencia del Defensor del Pueblo", XII Jornadas de Coordinación entre Defensores del Pueblo, Defensor del Pueblo Andaluz, Sevilla, 1998, págs. 393 a 400.

INFORMES

DEFENSOR DEL PUEBLO

Agua y ordenación del territorio, Defensor del Pueblo, Madrid, 2010.

Centros de protección de menores con trastornos de conducta y en situación de dificultad social, Defensor del Pueblo, Madrid, 2009.

Violencia escolar: el maltrato entre iguales en la Educación Secundaria Obligatoria 1999-2006, Defensor del Pueblo, Madrid, 2007.

Informe sobre daño cerebral sobrevenido en España: un acercamiento epidemiológico y sociosanitario, Defensor del Pueblo, Madrid, 2006.

Informe sobre asistencia jurídica a los extranjeros en España, Defensor del Pueblo, Madrid, 2005.

Informe sobre contaminación acústica, Defensor del Pueblo, Madrid, 2005.

Funcionarios interinos y personal eventual: la provisionalidad y temporalidad en el empleo público, Defensor del Pueblo, Madrid, 2003.

Escolarización del alumnado de origen inmigrante en España: análisis descriptivo y estudio empírico, Defensor del Pueblo, Madrid, 2003.

Recursos ante el Tribunal Constitucional, 1993-2002, Defensor del Pueblo, Madrid, 2003.

Listas de espera en el Sistema Nacional de Salud, Defensor del Pueblo, Madrid, 2002. 
El primer año de vigencia de la ley reguladora de la responsabilidad penal de los menores, Defensor del Pueblo, Madrid, 2002.

Presente y futuro de la fiscalidad del discapacitado, Defensor del Pueblo, Madrid, 2000.

Violencia escolar: el maltrato entre iguales en la educación secundaria obligatoria, Defensor del Pueblo, Madrid, 2000.

Informe sobre la gestión de los residuos urbanos en España, Defensor del Pueblo, Madrid, 2000.

La atención sociosanitaria en España: perspectiva gerontológica y otros aspectos conexos, Defensor del Pueblo, Madrid, 2000.

La violencia doméstica contra las mujeres, Defensor del Pueblo, Madrid, 1998

Seguridad y prevención de accidentes en áreas infantiles, Defensor del Pueblo, Madrid, 1997.

Situación penitenciaria y depósitos municipales de detenidos 1988-1996, Defensor del Pueblo, Madrid, 1997.

Estudio y recomendaciones del Defensor del Pueblo sobre la atención residencial a personas con discapacidad y otros aspectos conexos, Defensor del Pueblo, Madrid, 1996.

Situación jurídica y asistencial de los extranjeros en España, Defensor del Pueblo, Madrid, 1994.

Recursos ante el Tribunal Constitucional 1988-1992, Defensor del Pueblo, Madrid, 1993.

Estudio sobre la situación del menor en centros asistenciales y de internamiento y recomendaciones sobre el ejercicio de las funciones protectora y reformadora, Defensor del Pueblo, Madrid, 1991.

Estudio y recomendaciones del Defensor del Pueblo sobre la situación jurídica $y$ asistencial del enfermo mental en España, Defensor del Pueblo, Madrid, 1991.

Residencias públicas y privadas de la tercera edad, Defensor del Pueblo, Madrid, 1990.

Situación penitenciaria en Cataluña, Defensor del Pueblo, Madrid, 1990.

Situación penitenciaria en España, Defensor del Pueblo, Madrid, 1988.

Recursos ante el Tribunal Constitucional, 1983-1987, Defensor del Pueblo, Madrid, 1987.

\section{COMISIONADOS AUTONÓMICOS}

Andalucía: Defensor del Pueblo de ANDALUCía

Normativa sobre la participación ciudadana en las diputaciones provinciales $y$ en los grandes municipios de Andalucía, Defensor del Pueblo de Andalucía, Sevilla, 2009.

Ordenación del territorio y urbanismo en los informes de la oficina del defensor del pueblo andaluz, Defensor del Pueblo de Andalucía, Sevilla, 2009. 
Universidades y discapacidad, Defensor del Pueblo de Andalucía, Sevilla, 2008.

Lugares de custodia de personas detenidas: Depósitos municipales y otros calabozos policiales, Defensor del Pueblo de Andalucía, Sevilla, 2008.

Universidades y discapacidad: informe especial al Parlamento. Defensor del Pueblo Andaluz, Sevilla, 2008.

La atención a las personas mayores dependientes en Andalucía, Defensor del Pueblo de Andalucía, Sevilla, 2007.

La atención a las personas mayores dependientes en Andalucía, Defensor del Pueblo de Andalucía, Sevilla, 2007.

Menores con trastornos de conducta en Andalucia, Defensor del Pueblo de Andalucía, Sevilla, 2007.

Vivir en la calle: la situación de las personas sin techo en Andalucía, Defensor del Pueblo de Andalucía, Sevilla, 2006.

Los servicios domiciliarios de agua en Andalucia: informe especial al Parlamento, Defensor del Pueblo Andaluz, Sevilla, 2006.

Mujeres privadas de libertad en Centros Penitenciarios de Andalucía, Defensor del Pueblo de Andalucía, Sevilla, 2006.

Chabolismo en Andalucia, Defensor del Pueblo, Sevilla, 2005.

Discapacitados y acceso al empleo de las Administraciones Públicas, Defensor del Pueblo de Andalucía, Sevilla, 2004.

La incidencia de las drogas en la población inmigrante y extranjera comunitaria, Defensor del Pueblo de Andalucía, Sevilla, 2004.

Menores inmigrantes en Andalucía. La atención en los centros de protección de menores, Defensor del Pueblo de Andalucía, Sevilla, 2004.

Veinte años de intervenciones del Defensor del Pueblo Andaluz en defensa de los derechos de las personas con discapacidad en Andalucía, Defensor del Pueblo de Andalucía, Sevilla, 2003.

Personas prisioneras en sus viviendas, Defensor del Pueblo de Andalucía, Sevilla, 2003.

Situación de los juzgados de paz en Andalucía, Defensor del Pueblo de Andalucía, Sevilla, 2003.

Protección y seguridad en centros docentes de Andalucía, Defensor del Pueblo de Andalucía, Sevilla, 2003.

La situación de las drogas y otras adicciones en Andalucía, Defensor del Pueblo de Andalucía, Sevilla, 2002.

Internet como instrumento de participación y garantía de transparencia en el ámbito urbanistico, Defensor del Pueblo de Andalucía, Sevilla, 2002

La atención ciudadana en Andalucía: Los servicios de información administrativa y atención ciudadana en Andalucía, Defensor del Pueblo de Andalucía, Sevilla, 2002.

La Prostitución: Realidad y Politicas de Intervención Pública en Andalucía, Defensor del Pueblo de Andalucía, Sevilla, 2002.

Recolección de aceitunas en la provincia de Jaén: programas de apoyo para trabajadores temporeros, Defensor del Pueblo de Andalucía, Sevilla, 2001. 
El alojamiento y la vivienda de los trabajadores inmigrantes en la provincia de Huelva, Defensor del Pueblo de Andalucía, Sevilla, 2001.

Estudio de actualización del Informe: Pasos a nivel en Andalucia, Defensor del Pueblo de Andalucía, Sevilla, 2001.

El acogimiento familiar en Andalucía, Defensor del Pueblo de Andalucía, Sevilla, 2001.

El alojamiento y la vivienda de los trabajadores inmigrantes en el poniente almeriense y campo de Níjar, Defensor del Pueblo de Andalucía, Sevilla, 2001.

Recolección de aceitunas en la provincia de Jaén: programas de apoyo para trabajadores temporeros: informe especial al Parlamento, Defensor del Pueblo Andaluz, Sevilla, 2001.

Bibliotecas públicas municipales: el derecho de todos a acceder a la cultura. Informe especial al Parlamento, Defensor del Pueblo Andaluz, Sevilla, 2001.

Servicios municipales de protección civil y su coordinación: informe especial al Parlamento, Defensor del Pueblo Andaluz, Sevilla, 2001.

Deficientes mentales internados en centros penitenciarios andaluces, Defensor del Pueblo de Andalucía, Sevilla, 2000.

Las urbanizaciones ilegales en Andalucia: informe especial al Parlamento, Defensor del Pueblo Andaluz, Sevilla, 2000.

El sistema de protección de menores: informe especial al Parlamento, Defensor del Pueblo Andaluz, Sevilla, 1999.

Las estaciones de autobuses en Andalucia, Defensor del Pueblo de Andalucía, Sevilla, 1999.

Residuos de cebaderos y granjas avicolas en Andalucía, Defensor del Pueblo de Andalucía, Sevilla, 1999.

Los arrestos de fin de semana: Su desarrollo en Andalucía, Defensor del Pueblo de Andalucía, Sevilla, 1999.

El sistema de protección de menores, Defensor del Pueblo de Andalucía, Sevilla, 1999.

La situación de los drogodependientes en las cárceles andaluzas, Defensor del Pueblo de Andalucía, Sevilla, 1999.

El absentismo escolar: un problema educativo y social, Defensor del Pueblo de Andalucía, Sevilla, 1998.

Las viviendas provisionales en Andalucía, Defensor del Pueblo de Andalucía, Sevilla, 1998.

Colaboración entre la Junta de Andalucía y la Administración Central en materia penitenciaria, Defensor del Pueblo de Andalucía, Sevilla, 1998.

La contaminación visual del patrimonio histórico andaluz: el impacto visual en los bienes del patrimonio histórico-artístico causado por el cableado, antenas y otras instalaciones, Defensor del Pueblo de Andalucía, Sevilla, 1998.

Viviendas provisionales en Andalucía: informe especial al Parlamento, Defensor del Pueblo Andaluz, Sevilla, 1998. 
La atención socio-sanitaria a los enfermos de SIDA en Andalucía, Defensor del Pueblo de Andalucía, Sevilla, 1997.

Situación de los enfermos mentales internados en centros penitenciarios andaluces, Defensor del Pueblo de Andalucía, Sevilla, 1997.

Temporeros y educación: la atención educativa a los hijos de trabajadores temporeros, Defensor del Pueblo de Andalucía, Sevilla, 1997.

Pasos a nivel en Andalucía, Defensor del Pueblo de Andalucía, Sevilla, 1997.

Contaminación acústica en Andalucía derivada de actividades recreativas y consumo de bebidas en las vías públicas, Defensor del Pueblo de Andalucía, Sevilla, 1996.

Los depósitos municipales de detenidos en Andalucía, Defensor del Pueblo de Andalucía, Sevilla, 1996.

La situación de los presos andaluces que cumplen condenas en centros penitenciarios fuera de andalucía: Informe al Parlamento de Andalucía, Defensor del Pueblo Andaluz, Sevilla, 1996.

Procedimientos de selección y provisión en la administración de la Junta de Andalucía, Defensor del Pueblo de Andalucía, Sevilla, 1995.

El servicio de ayuda a domicilio en las capitales andaluzas, Defensor del Pueblo de Andalucía, Sevilla, 1995.

Las barreras en Andalucia: la accesibilidad y eliminación de las barreras arquitectónicas, urbanisticas y en el transporte en Andalucia, Defensor del Pueblo de Andalucía, Sevilla, 1994.

La situación de las listas de espera en las prótesis de cadera en Andalucía, Defensor del Pueblo Andaluz, Sevilla, 1993.

Informe sobre el estado sanitario y ambiental de las playas andaluzas, Defensor del Pueblo Andaluz, Sevilla, 1991.

\section{Aragón: JUSTICIA DE ARAGÓN}

Informe especial sobre los incendios forestales en Aragón, Justicia de Aragón, Zaragoza, 2010.

Informe sobre la situación de los menores en Aragón 2009, Justicia de Aragón, Zaragoza, 2010.

Informe sobre la situación de los menores en Aragón 2008, Justicia de Aragón, Zaragoza, 2009.

Informe sobre la procedencia de la solicitud al Gobierno de Aragón de la disolución del Ayuntamiento de La Muela, Justicia de Aragón, Zaragoza, 2009.

Modelos de actuación en violencia de género. Estudio piloto en Aragón, Justicia de Aragón, Zaragoza, 2009.

Estudio sobre las personas con capacidad intelectual límite, Justicia de Aragón, Zaragoza, 2008.

Detección y resolución de conflictos en el ámbito escolar, Justicia de Aragón, Zaragoza, 2008. 
Juventud y deportes, Justicia de Aragón, Zaragoza, 2008.

Juventud e idiomas, Justicia de Aragón, Zaragoza, 2008.

La prevención de la muerte homicida doméstica: un nuevo enfoque, Justicia de Aragón, Zaragoza, 2007.

Informe sobre la situación de las residencias para personas mayores en Aragón, Justicia de Aragón, Zaragoza, 2007.

Puntos negros y planteamientos alternativos para las carreteras de Aragón, Justicia de Aragón, Zaragoza, 2007.

El problema de las listas de espera en el ámbito sanitario, Justicia de Aragón, Zaragoza, 2006.

Situación de los discapacitados en Teruel, Justicia de Aragón, Zaragoza, 2006.

El maltrato a la infancia. Informe especial sobre los malos tratos en el seno familiar y la violencia de hijos a padres, Justicia de Aragón, Zaragoza, 2005.

Informe sobre la enfermedad celiaca: situación de los enfermos celiacos en Aragón, Justicia de Aragón, Zaragoza, 2005.

Proceso de admisión de alumnos en Centros sostenidos con fondos públicos, Justicia de Aragón, Zaragoza, 2005.

Informe sobre la situación de las personas sordas en Aragón, Justicia de Aragón, Zaragoza, 2004.

La integración de los inmigrantes en Aragón: Vivienda, Trabajo y Educación, Justicia de Aragón, Zaragoza, 2004.

Calidad de vida de las personas mayores. Un supuesto especial: el maltrato, Justicia Mayor de Aragón, Zaragoza, 2004.

Valoración y seguimiento del problema de la siniestralidad laboral en Aragón, Justicia de Aragón, Zaragoza, 2004.

La violencia vial. Informe especial sobre los accidentes de tráfico en Aragón, Justicia de Aragón, Zaragoza, 2004.

Qué piensan nuestros jóvenes de las drogas? ¿Y del alcohol como una de ellas? ¿Y de su influencia en la posibilidad de conducir vehículos?, Justicia de Aragón, Zaragoza, 2003.

Dejar y Marchar. Testimonios sobre la Casa Aragonesa a finales del siglo XX, Justicia de Aragón, Zaragoza, 2003.

La imagen de las mujeres inmigrantes en los medios de comunicación. Aproximación al caso de Aragón, Justicia de Aragón, Zaragoza, 2003.

La imagen de las mujeres inmigrantes en los medios de comunicación. Aproximación al caso de Aragón, Justicia de Aragón, Zaragoza, 2003.

Dejar y Marchar. Testimonios sobre la Casa Aragonesa a finales del siglo XX, Justicia de Aragón, Zaragoza, 2003.

Las lesiones por agresión o en accidente de tráfico como indicadores de salud en la sociedad de Zaragoza, Justicia de Aragón, Zaragoza, 2002.

Informe especial sobre medio ambiente urbano en Aragón, Justicia de Aragón, Zaragoza, 2002.

Las lesiones por agresión o en accidente de tráfico como indicadores de salud en la sociedad de Zaragoza, Justicia de Aragón, Zaragoza, 2002. 
Informe Especial sobre la violencia juvenil en Aragón, Justicia de Aragón, Zaragoza, 2002.

El problema de la siniestralidad laboral en Aragón, Justicia de Aragón, Zaragoza, 2001.

Informe Especial sobre la vivienda en Aragón, Justicia de Aragón, Zaragoza, 2001.

Informe Especial sobre instalaciones de telefonía móvil en la Comunidad Autónoma de Aragón, Justicia de Aragón, Zaragoza, 2001.

Informe Especial sobre los problemas de ruidos y vibraciones en nuestras ciudades, Justicia de Aragón, Zaragoza, 2000.

Informe Especial sobre la despoblación en Aragón, Justicia de Aragón, Zaragoza, 2000.

Informe especial sobre el maltrato de las mujeres y los niños en el seno familiar: la violencia doméstica en Aragón, Justicia de Aragón, Zaragoza, 2000.

Informe Especial sobre el estado de la ordenación forestal en Aragón, Justicia de Aragón, Zaragoza, 1999.

Informe Especial sobre el consumo abusivo de alcohol por los menores en Aragón, Justicia de Aragón, Zaragoza, 1999.

El nuevo justiciazgo: 1988-1993 (análisis de un quinquenio), Justicia de Aragón, Zaragoza, 1993.

\section{Asturias: ProcuRador GENERAL DEL PRINCIPADo DE Asturias}

Informe monográfico sobre las personas sin hogar en el Principado de Asturias, Procurador General del Principado de Asturias, 2009.

Informe monográfico sobre la protección de los menores extranjeros no acompañados en Asturias, Procurador General del Principado de Asturias, 2008.

\section{Castilla-la Mancha: Defensor del Pueblo}

Informe sobre la seguridad de niños y niñas en instalaciones de ocio en parques y jardines, Defensor del Pueblo de Castilla y La Mancha, 2010.

Informe sobre el uso y peso de las mochilas y carritos entre los escolares, Defensor del Pueblo de Castilla y La Mancha, 2010.

Informe sobre centros de reforma de menores, Defensor del Pueblo de Castilla y La Mancha, 2007.

Informe sobre prisiones, Defensor del Pueblo de Castilla y La Mancha, 2007. Informe sobre enseñanza intercultural en la etapa de educación infantil, Defensor del Pueblo de Castilla y La Mancha, 2003. 


\section{Castilla y León: DiPUTADO DEL COMÚN}

Informe sobre menores víctimas de violencia de género, Diputado del Común, 2010.

Informe sobre la aplicación de la Ley de Dependencia en Castilla y León, Diputado del Común, 2009.

Informe sobre la situación del autismo en Castilla y León, Diputado del Común, 2009

Informe sobre la el problema del consumo del alcohol entre la población menor de Castilla y León, Diputado del Común, 2009.

Informe sobre la promoción de las viviendas protegidas en Castilla y León, Diputado del Común, 2009.

Informe sobre la situación de la banda ancha en Castilla y León, Diputado del Común, 2009.

Informe sobre la provisión de plazas de auxiliar administrativo, Diputado del Común, 2009.

Informe sobre la situación de las estaciones de transporte de viajeros en Castilla y León, Diputado del Común, 2008.

Informe sobre la enfermedad celiaca. La situación en Castilla y León, Diputado del Común, 2008.

Informe sobre parques infantiles, Diputado del Común, 2008.

Informe sobre salud Mental, Diputado del Común, 2006.

Informe especial de menores, Diputado del Común, 2004.

Informe especial sobre la situaciçon de las infracciones y sanciones en materia de tráfico urbano, Diputado del Común, 2004.

Informe sobre tercera edad. La atención residencial de la tercera edad en Castilla y León, Diputado del Común, 1998.

Informe sobre personas con discapacidades, Diputado del Común, 1998.

\section{CATALuña: SindiC DE GREUGES}

La provisió i l'accés als serveis de transport i menjador escolars, Sindic de Greuges, Barcelona, 2010.

La protecció a la infància en situació d'alt risc social a Catalunya, Sindic de Greuges, Barcelona, 2019.

La segregació escolar a Catalunya, Sindic de Greuges, Barcelona, 2008.

La gestió municipal de l'empadronament dels immigrants, Sindic de Greuges, Barcelona, 2008.

El tractament de l'assetjament psicològic en el marc de les administracions públiques catalanes, Sindic de Greuges, Barcelona, 2008

Estudi comparatiu dels sistemes penitenciaris europeus $i$ català, Sindic de Greuges, Barcelona, 2007.

L'escolarització de o a 3 anys a Catalunya, Sindic de Greuges, Barcelona, 2007. 
El dret a l'habitatge: obstacles i limits, Sindic de Greuges, Barcelona, 2007.

Informe sobre contaminació acústica, Sindic de Greuges, Barcelona, 2007.

Convivència i conflictes als centres educatius, Sindic de Greuges, Barcelona, 2006.

La protecció social dels treballadors autònoms, Sindic de Greuges, Barcelona, 2006.

L'accés a Internet mitjançant la connexió de banda ampla: un dret que cal universalitzar, Sindic de Greuges, Barcelona, 2006.

La situació dels menors immigrats sols, Sindic de Greuges, Barcelona, 2005.

El fenomen sense llar a Catalunya, Sindic de Greuges, Barcelona, 2005.

Informe extraordinari del Sindic de Greuges sobre l'atenció a la gent gran dependent a Catalunya, Sindic de Greuges, Barcelona, 2004.

Informe extraordinari sobre el servei públic de subministrament elèctric, una reflexió sobre els drets dels ciutadans, Sindic de Greuges, Barcelona, 2004.

Informe extraordinari del Sindic de Greuges al Parlament de Catalunya sobre els centres residencials d'atenció educativa per a infants $i$ adolescents a Catalunya, Sindic de Greuges, Barcelona, 2003.

Informe extraordinari del Sindic de Greuges sobre l'Aproximació a la situació de l'atenció primària de la salut a Catalunya, Sindic de Greuges, Barcelona, 2002.

Informe extraordinari del Sindic de Greuges sobre l'actuació de l'Administració pública en matèria de prevenció $i$ intervenció davant el risc d'inundacions $i$ avingudes, Sindic de Greuges, Barcelona, 2000.

Informe extraordinari sobre els centres d'acolliment per a infants desemparats, Sindic de Greuges, Barcelona, 1999.

Informe extraordinari sobre els espais de joc a Catalunya, Sindic de Greuges, Barcelona, 1999.

Informe sobre els dipòsits municipals de detinguts a Catalunya: entre la imprevisió i l'omissió, Sindic de Greuges, Barcelona, 1991.

\section{GALICIA: VALEDOR DO POBO}

Menores vulnerables: desprotección y responsabilidad penal, Valedor do Pobo, Santiago, 2007.

Informe extraordinario sobre la seguridad viaria en Galicia, Valedor do Pobo, Santiago, 2006

Informe sobre la situación de la población Gitana en Galicia, Valedor do Pobo, Santiago, 2005.

Informe sobre la discriminación, marginación y exclusión social en Galicia, Defensor do Povo, 1998.

Informe: Ser viejo en Galicia, Defensor do Povo, 1994.

Informe sobre la contaminación acústica en Galicia, Valedor do Pobo, Santiago, 1996. 


\section{Islas CANARIAS: DIPUTADO DEL COMÚN}

Informe sobre exclusión social extrema, Diputado del Común, 2008.

Informe sobre la tutela jurisdiccional en Canarias, Diputado del Común, 2005.

Informe sobre la problemática del absentismo escolar en las provincias de la Comunidad Autónoma Canaria, Diputado del Común, 2005.

Informe sobre la situación de los menores en el CAI de la Cuesta, Diputado del Común, 2004.

\section{La Rioja: Defensor del Pueblo Riojano}

Informe especial: Avance sobre la aplicación de la Ley de promoción de la autonomía personal y atención a las personas en situación de dependencia (I), Defensor del Pueblo riojano, 2009.

Informe especial sobre las lenguas de signos: un medio de comunicación de las personas sordas con discapacidad auditiva y sordo ciegas, Defensor del Pueblo riojano, 2009.

Informe extraordinario La matriculación del alumnado inmigrante en los centros públicos y concertados para las Enseñanzas Infantil y Primaria dentro del término municipal de Logroño, Defensor del Pueblo riojano, 2009.

Informe extraordinario sobre la convivencia escolar en La Rioja, Defensor del Pueblo riojano, 2008.

Informe extraordinario sobre la enfermedad celíaca en La Rioja, Defensor del Pueblo riojano, 2008.

Informe sobre los Derechos de los Administrados ante el Silencio de las Administraciones Públicas Riojanas, Defensor del Pueblo riojano, 2008.

Navarra: Defensor del Pueblo DE NaVARRA

El bilingüismo y la situación de los derechos lingüísticos de los ciudadanos, Universidad de Navarra, Institución de la Defensora del Pueblo de la Comunidad Foral de Navarra, 2010.

La publicidad exterior de bebidas alcohólicas y sus efectos negativos en menores de edad, Universidad de Navarra, Institución de la Defensora del Pueblo de la Comunidad Foral de Navarra, 2009.

El servicio de transporte lanzadera colectivo y adaptado para el acceso a consulta y pruebas de atención médica especializada, Universidad de Navarra, Institución de la Defensora del Pueblo de la Comunidad Foral de Navarra, 2009.

Desarrollo de las competencias del Defensor del Pueblo de Navarra en relación con las garantías de los derechos de los extranjeros y los inmigrantes, Universidad de Navarra, Institución de la Defensora del Pueblo de la Comunidad Foral de Navarra, 2009. 
Catálogo de prestaciones y cartera de servicios del sistema sanitario de Navarra, Universidad de Navarra, Institución de la Defensora del Pueblo de la Comunidad Foral de Navarra, 2009.

Desarrollo de las competencias del Defensor del Pueblo en relación con la igualdad efectiva de hombres y mujeres, Universidad de Navarra, Institución de la Defensora del Pueblo de la Comunidad Foral de Navarra, 2009.

Ampliación de competencias del Defensor del Pueblo de Navarra en materia de protección de menores, Universidad de Navarra, Institución de la Defensora del Pueblo de la Comunidad Foral de Navarra, 2009.

La situación de menores extranjeros no acompañados en la Comunidad Foral de Navarra, Universidad de Navarra, Institución de la Defensora del Pueblo de la Comunidad Foral de Navarra, 2008.

El régimen jurídico de plazos preclusivos para la impugnación del silencio administrativo, Universidad de Navarra, Institución de la Defensora del Pueblo de la Comunidad Foral de Navarra, 2008.

La competencia de los Concejos de Navarra, Universidad de Navarra, Institución de la Defensora del Pueblo de la Comunidad Foral de Navarra, 2008.

El sistema tributario foral de Navarra, Universidad de Navarra, Institución de la Defensora del Pueblo de la Comunidad Foral de Navarra, 2008.

El silencio administrativo en la actividad urbanistica, Universidad de Navarra, Institución de la Defensora del Pueblo de la Comunidad Foral de Navarra, 2008.

La violencia en el ámbito de la Administración sanitaria, Universidad de Navarra, Institución de la Defensora del Pueblo de la Comunidad Foral de Navarra, 2008.

La actuación de las Administraciones Públicas de Navarra en materia de protección de menores, Universidad de Navarra, Institución de la Defensora del Pueblo de la Comunidad Foral de Navarra, 2008.

Una sociedad para todas las edades. Los mayores también cuentan, Universidad de Navarra, Institución de la defensora del Pueblo de la Comunidad Foral de Navarra, 2007.

La contaminación acústica en la Comunidad Foral, Universidad de Navarra, Institución de la Defensora del Pueblo de la Comunidad Foral de Navarra, 2007.

La accesibilidad física y sensorial en Navarra, Universidad de Navarra, Institución de la Defensora del Pueblo de la Comunidad Foral de Navarra, 2007.

Medidas sociales, sanitarias y educativas que debieran preverse para el nuevo centro penitenciario, Universidad de Navarra, Institución de la Defensora del Pueblo de la Comunidad Foral de Navarra, 2007.

La atención a la dependencia de las personas mayores en Navarra, Universidad de Navarra, Institución de la Defensora del Pueblo de la Comunidad Foral de Navarra, 2005.

Derechos humanos y prostitución en Navarra, Universidad de Navarra, Institución de la Defensora del Pueblo de la Comunidad Foral de Navarra, 2005. 
Los derechos de la infancia: informe especial, Defensor del Pueblo de Navarra, Pamplona, 2004.

Una identidad para la infancia. La atención a la educación infantil entre 0 y 3 años en Navarra, Universidad de Navarra, Institución de la Defensora del Pueblo de la Comunidad Foral de Navarra, 2004.

La conservación del patrimonio artístico del museo y casa-museo Jorge Oteiza, Universidad de Navarra, Institución de la Defensora del Pueblo de la Comunidad Foral de Navarra, 2004.

La atención a la salud mental en Navarra, Universidad de Navarra, Institución de la Defensora del Pueblo de la Comunidad Foral de Navarra, 2003.

La inmigración en la ribera de Navarra, Universidad de Navarra, Institución de la Defensora del Pueblo de la Comunidad Foral de Navarra, 2002.

\section{PAÍS VASCO: ARARTEKO}

Informe sobre la atención institucional a las víctimas del terrorismo en Euskadi: informe extraordinario de la institución del Ararteko al Parlamento Vasco, Ararteko, Vitoria, 2009.

La situación de las personas transgénero y transexuales en Euskadi: informe extraordinario de la institución del Ararteko al Parlamento Vasco, Ararteko, Vitoria, 2009.

Informe sobre agua y ordenación del territorio, Defensor del Pueblo, Madrid, 2009.

Las politicas públicas de vivienda dirigidas a la población jovén en la CAPV: informe extraordinario de la institución del Ararteko al Parlamento Vasco, Ararteko, Vitoria, 2007.

Respuesta a las necesidades básicas de las personas sin hogar y en exclusión grave: informe extraordinario de la institución del Ararteko al Parlamento Vasco, Ararteko, Vitoria, 2006.

Situación de los menores extranjeros no acompañados en la CAPV: informe extraordinario de la institución del Ararteko al Parlamento Vasco, Ararteko, Vitoria, 2005.

Respuesta institucional a la violencia contra las mujeres en la CAPV: informe extraordinario de la institución del Ararteko al Parlamento Vasco, Ararteko, Vitoria, 2003.

Accesibilidad en edificios de uso público de la Comunidad Autónoma del País Vasco: informe extraordinario de la institución del Ararteko al Parlamento, Ararteko, Vitoria, 2003.

La integración laboral de las personas con discapacidad en la CAPV: informe extraordinario de la institución del Ararteko al Parlamento Vasco, Ararteko, Bilbao, 2003.

Respuesta institucional a la violencia contra las mujeres en la CAPV: informe extraordinario de la institución del Ararteko al Parlamento Vasco, Ararteko, Vitoria, 2003. 
La situación de la población temporera en Álava: condiciones del trabajo temporero en las campañas de vendimia y recolección de patata. Informe extraordinario de la institución del Ararteko al Parlamento Vasco, Ararteko, Vitoria, 2002.

La respuesta a las necesidades educativas especiales en la CAPV, Ararteko, Vitoria, 2001.

Atención comunitaria de la enfermedad mental: las personas con enfermedad mental crónica que reciben atención no hospitalaria en la CAPV. Informe extraordinario al Parlamento, Ararteko, Vitoria, 2000.

Protección de la calidad del agua en los embalses del sistema Zadorra: informe extraordinario del Ararteko al Parlamento Vasco. Ararteko, Vitoria, 1999.

La situación de los servicios sociales de base en la CAPV: informe extraordinario del Ararteko al Parlamento Vasco, Ararteko, Vitoria, 1999.

Intervención con infractores menores de edad penal: informe extraordinario del Ararteko al Parlamento Vasco, Ararteko, Vitoria, 1998.

Atención a la infancia y a la adolescencia en situación de desprotección en la Comunidad Autónoma del País Vasco: Informe extraordinario del Ararteko al Parlamento Vasco, Ararteko, Vitoria, 1997.

Informe extraordinario sobre la asistencia no residencial a la tercera edad en la Comunidad Autónoma del País Vasco, Ararteko, Vitoria, 1996.

Situación de las cárceles en el País Vasco: informe extraordinario del Ararteko al Parlamento Vasco, Ararteko, Vitoria, 1996.

Cinco años de la institución del Ararteko en el País Vasco 1989-1994, Ararteko, Vitoria, 1994.

Las residencias de tercera edad en la Comunidad Autónoma vasca, Ararteko, Vitoria, 1994.

Las residencias de tercera edad en la Comunidad Autónoma vasca: informe extraordinario al Parlamento Vasco 1992-1993, Ararteko, Vitoria, 1994.

Los psiquiátricos: situación de los enfermos mentales en hospitales psiquiátricos, Ararteko, Vitoria, 1992.

Los calabozos. Centros de detención municipales y de la Ertaintza, Ararteko, Vitoria, 1991.

\section{Comunidad Valenciana: SindiC DE GREUGES}

La escuela: espacio de convivencia y conflictos, Sindic de Greuges, Valencia, 2007. El acceso a la vivienda en la comunidad valenciana por los colectivos sociales más desfavorecidos, Sindic de Greuges, Valencia, 2005.

Situación en la comunidad valenciana de los instrumentos destinados a garantizar el cumplimiento de los deberes de edificación y conservación de inmuebles, Sindic de Greuges, Valencia, 2005.

Respuesta institucional a la violencia contra la mujer en las relaciones de pareja en la comunidad valenciana, Sindic de Greuges, Valencia, 2005. 
La implantación de los medios para hacer efectivas las medidas de reforma previstas en la ley orgánica 5/2000, Sindic des Greuges, Valencia, 2005.

Informe a las cortes valencianas sobre los temas propuestos por la ponencia encargada de realizar un estudio para una posible reforma del estatuto de autonomía, Sindic de Greuges, Valencia, 2005.

Contaminación acústica en las actividades de ocio. Establecimientos con ambientación musical y prácticas de consumo en la vía pública, Sindic de Greuges, Valencia, 2004.

La actividad urbanistica en la comunidad valenciana. Principales preocupaciones y quejas de los ciudadanos, Sindic de Greuges, Valencia, 2004. Situación de las personas que padecen enfermedades mentales y de sus familiares, Sindic de Greuges, Valencia, 2003.

TITLE: Bibliographic Repertory on the Ombudsman.

ABSTRACT: Present digest gathers the diverse studies, already books, articles in scientific reviews or chapters of books, which have approached from the perspectives of the Ombudsman and other activities that our Constitution entrusts it. In order to facilitate the use of the digest, the studies are classified in eight different topics taking into consideration its principal subject. Last topic includes documents and reports.

RESUMEN: El presente repertorio bibliográfico recoge los diversos estudios, ya sean monografias, artículos en revistas especializadas o capítulos de libros, que han abordado desde las más diversas perspectivas la figura del Defensor del Pueblo y las diferentes actividades que le encomienda nuestra Carta Magna. Para facilitar el manejo del repertorio los diferentes estudios se encuadran, según sea su temática principal, en alguno de los ocho apartados en los que se divide. En el último apartado se recogen los diversos documentos e informes realizados por el defensor del Pueblo y sus homólogos comisionados autonómicos.

KEY WORDS: Ombudsman. Repertoire.

Palabras clave: Defensor del Pueblo. Repertorio.

FECHA DE RECEPCIÓN: 30.06.2010. FECHA DE ACEPTACIÓN: 28.07.2010. 